DOI: $10.1002 /$ adfm.201402288

Article type: Feature Article

\title{
All solution-processed chalcogenide solar cells - from single functional layers towards a $13.8 \%$ efficient CIGS device
}

Yaroslav E. Romanyuk*, Harald Hagendorfer, Patrick Stücheli, Peter Fuchs, Alexander R. Uhl, Carolin M. Sutter-Fella, Melanie Werner, Stefan Haass, Josua Stückelberger, Cédric Broussillou, Pierre-Philippe Grand, Veronica Bermudez, and Ayodhya N. Tiwari

Dr. Y. E. Romanyuk, Dr. H. Hagendorfer, P. Stücheli, P. Fuchs, Dr. A. R. Uhl, Dr. C. M. Sutter-Fella, M. Werner, S. Haass, J. Stückelberger, and Prof. A. N. Tiwari Laboratory for Thin Films and Photovoltaics, Empa - Swiss Federal Laboratories for Materials Science and Technology, 8600 Dübendorf, Switzerland E-mail: yaroslav.romanyuk@empa.ch

Dr. A. R. Uhl

Department of Chemical Engineering, University of Washington, Seattle, WA 98195, USA

Dr. C. Broussillou, Dr. P.-P. Grand, Dr. V. Bermudez

NEXCIS Photovoltaic Technology, 13790 Rousset, France

Keywords: photovoltaic devices, semiconductors, solar cells, thin films, zinc oxide

Solution processing of inorganic thin films has become an important thrust in material research community because it offers low-cost and high-throughput deposition of various functional coatings and devices. Especially inorganic thin film solar cells - macroelectronic devices that rely on consecutive deposition of layers on large-area rigid and flexible substrates - could benefit from solution approaches in order to realize their low-cost nature. This article critically reviews existing deposition approaches of functional layers for chalcogenide solar cells with an extension to other thin film technologies. Only true solutions of readily available metal salts in appropriate solvents are considered without the need of pre-fabricated nanoparticles. By combining three promising approaches, an air-stable $\mathrm{Cu}(\mathrm{In}, \mathrm{Ga}) \mathrm{Se}_{2}$ thin film solar cell with efficiency of $13.8 \%$ is demonstrated where all constituent layers (except the metal back contact) are processed from solutions. Notably, water is employed as the solvent in all steps, highlighting the potential for safe manufacturing with high utilization rates. 


\section{WILEY-VCH}

\section{Introduction}

Thin film solar cells (TFSC) are photovoltaic (PV) devices that are made by depositing multiple layers of different functionalities with a total thickness on the order of 1-5 micrometers on rigid or flexible substrates. Within the past few years not just one but several thin film PV technologies have demonstrated remarkable improvements in conversion efficiency. ${ }^{[1]}$ The highest efficiency of $21.0 \%$ amongst all TFSC currently belongs to the $\mathrm{Cu}(\mathrm{In}, \mathrm{Ga}) \mathrm{Se}_{2}$ (CIGS) solar cells, ${ }^{[2]}$ and the performance of CdTe cells has been boosted from $16.5 \%$ to $20.4 \%$ in just 3 years. ${ }^{[3]}$ Remarkably, both CIGS and CdTe records are equal to or exceeding the highest value of $20.4 \%$ for the market leading polycrystalline silicon wafer technology. Kesterite $\mathrm{Cu}_{2} \mathrm{ZnSn}(\mathrm{S}, \mathrm{Se})_{4}(\mathrm{CZTSSe})$ solar cells are often considered as low-cost alternatives to CIGS and CdTe because they consist of only earth-abundant and non-toxic elements although the efficiency is currently limited to $12.6 \%{ }^{[4]}$ Well-established dyesensitized (DCCS) and amorphous silicon (a-Si) technologies peak at 12.3\% and 13.4\%, respectively. ${ }^{[1]}$ The most recent boom in TFPV - organometallic halide perovskite cells - has shown an incredible spurt by advancing efficiency from below $5 \%$ to $17.9 \%(!)$ within just 3 years. $^{[5]}$ On the border to classical TFSC is the thin crystalline silicon technology that employs lift-off of 50-micron-thick Si wafers to yield up to $21.2 \%$-efficient solar cells. ${ }^{[6]}$

These massive research and development efforts in the field of TFSC clearly reflect their commercial value for manufacturing inexpensive efficient solar modules, - rigid or flexible. Functional layers for the high efficiency devices are deposited mostly in a batch-tobatch manner using vacuum-based methods such as evaporation, sputtering, or chemical vapor deposition. For example, Figure 1 exhibits a cross-section of a $>20 \%$ efficient CIGS solar cell in so-called substrate configuration, where 5 out of 6 functional layers are deposited by evaporation or sputtering. In this respect, non-vacuum deposition methods are often 


\section{WILEY-VCH}

promoted as alternative approaches to reduce capital investment costs, offer fast roll-to-roll (R2R) processing and eventually reduce the PV module prices. Particularly desirable among non-vacuum approaches are solution-based techniques due to their relative simplicity and potential economy. Switching to low-cost non-vacuum manufacturing is justified, however, only if the material performance comparable to the reference vacuum processes can be maintained. While vacuum-based methods typically result in higher-quality materials, there are several encouraging examples when non-vacuum processed solar cells outperform their vacuum-based analogues. CZTSSe absorbers deposited from hydrazine-based pure solutions yield the record of $12.6 \%$ efficient solar cells - higher than any evaporation or sputtering approach. ${ }^{[4]}$ The best organometallic perovskite cells currently reaching $16-18 \%$ efficiency values are also produced by depositing constituent layers with low-temperature solution methods (typically spin-coating) ${ }^{[5]}$

There are several recent reviews that praise liquid-processed photovoltaics, starting from the comprehensive book edited by D. Mitzi, ${ }^{[7]}$ an extensive overview of Habas et al., ${ }^{[8]}$ followed by more specific reviews of chalcopyrite ${ }^{[9]}$ and kesterite ${ }^{[10-12]}$ absorbers, as well as interface engineering concepts. ${ }^{[13]}$ In this article we would like to critically evaluate various solution deposition methods for creating a high-efficiency chalcogenide thin film solar cell, in which not just one but several functional layers are obtained by a scalable solution approach. The thin film CIGS or CZTSSe solar cell in the so-called substrate configuration (Figure 1) is chosen as the model system although our conclusions may be extended to other technologies employing similar functional layers. The discussion is limited only to pure (true) solution approaches that do not require pre-fabricated nanoparticles or complex organometallic precursors. With this restriction one should be able to fully exploit the low-cost nature of liquid processing so that readily available, cheap metal salts with long storage time (weeks to months) can be used as starting agents for reproducible, industrial scale manufacturing. To enhance the cost benefit even more, where possible, this approach is used in combination with 


\section{WILEY-VCH}

deposition techniques exhibiting a high degree of material utilization (e.g. electrodeposition with utilization of up to $90 \%$ ). Finally, the preference is given to methods that employ water as solvent in order to promote ecological manufacturing and diminish problems of liquid waste.

\section{State-of-art deposition method}

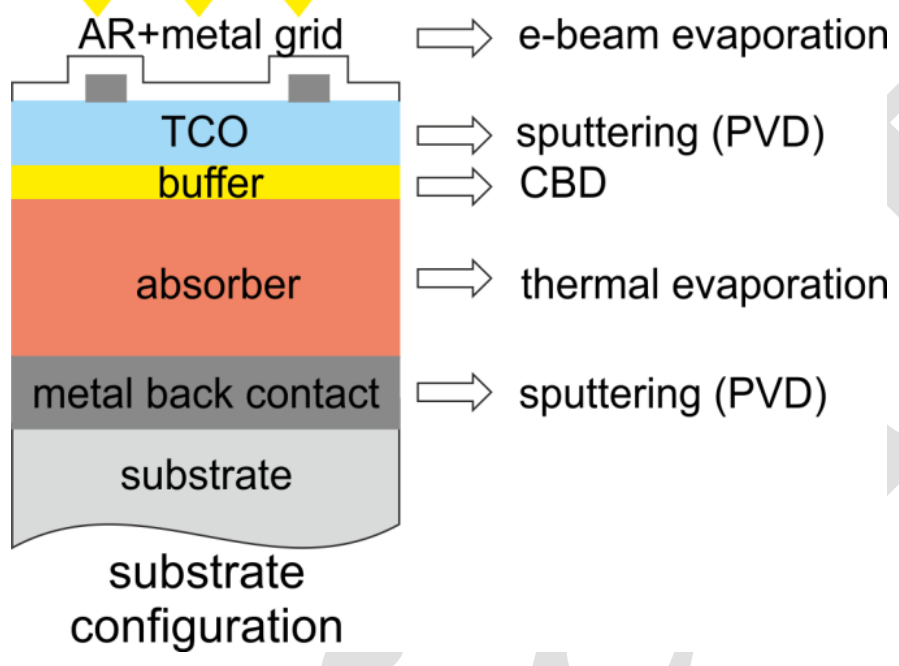

Figure 1. Structure of a typical chalcogenide thin film solar cell in substrate configuration. State-of-the-art deposition methods employed for the highest-efficiency devices are listed.

Thin films can be grown or coated from solutions with a number of deposition techniques, which could be conventionally divided into two categories depending on whether the substrate is immersed in a liquid (A) or a substrate is coated with a liquid (B):

A: growth methods can be defined as deposition methods where the substrate is immersed into a precursor solution during the layer growth. In the process of chemical bath deposition (CBD), the solution conditions (e.g. temperature, concentration, $\mathrm{pH}$ ) are tuned in order to obtain a supersaturated solution and thus induce nucleation and subsequent layer growth. Nucleation can occur either in the solution (homogenous) or on the surface of the immersed substrate (heterogenous). For a successful deposition of dense and uniform films heterogenous nucleation should be promoted. ${ }^{[14]}$ In the process of electrochemical deposition 


\section{WILEY-VCH}

(or simply electrodeposition - ED), electrolysis is used to grow thin films onto a conducting substrate that is immersed in a solution bath containing the ions of interest. ED can be used either to directly grow a desired phase or, more commonly, to first deposit (electroplate) metallic precursors which are later converted into a desired phase (e.g. annealing of electrodeposited $\mathrm{Cu} / \mathrm{In}$ precursors in selenium atmosphere to form $\mathrm{CuInSe}_{2}$ as described in Section 2.2.1). While ED always requires a conductive substrate, a major advantage of ED is a high material utilization since the bath can be reused multiples times when salts are replenished and no electrolyte degradation occurs. Other growth methods such as successive ionic layer adsorption and reaction (SILAR) - a CBD like process with multiple dipping cycles - are only used for research purposes. Several books and comprehensive reviews describe the basics and technology of $\mathrm{CBD}^{[15-17]}$ and $\mathrm{ED} .^{[18,19]}$

B: coating methods are characterized by distributing a liquid onto the surface of a substrate, followed by necessary thermal/chemical treatments to achieve the desired phase. Numerous liquid coating methods have been summarized previously. ${ }^{[9,20,21]}$. Coating techniques such as dip- and spin-coating, knife blading (aka. doctor blading), or ink-jet printing are commonly used on small scale. Slit-, slot- and die- casting as well as spraying methods (spray-pyrolysis, spray ion layer gas reaction (ILGAR), aerosol jet) are adapted for larger area substrates. High-productivity printing methods encompass screen-printing, flexography and gravure printing. In order to evaporate the solvent residues and obtain the desired phase, the coated precursor layer is heated in inert or reactive atmosphere, although activation with electromagnetic radiation may also be used. Coating methods such as spraypyrolysis are capable of yielding the final phase just in one step, without the need of additional post-annealing (e.g. spray-pyrolysis of sulphides or oxides described in Sections 2.3.3 and 2.4.2).

There is a vast amount of literature describing how individual layers of the CIGS and CZTS solar cell can be prepared using almost all methods from both categories. It is, however, 


\section{WILEY-VCH}

strongly desirable to limit the method of choice to potentially scalable approaches which allow achieving dense, homogenous, phase pure and polycrystalline thin films to be used in high performance devices. Since the criteria to judge the layer quality can be broad in terms of physical properties and depend on available characterization methods, we will consider the solar cell efficiency as the ultimate parameter to compare different solution approaches. By critically analyzing solution approaches in subsequent sections, we demonstrate that the polycrystalline semiconductor layers produced by the growth methods (category A) yield, on average, more efficient chalcogenide solar cells than those obtained by coating methods (category B).

\section{Solution deposition of individual layers}

\subsection{Metal back contact}

A highly conductive thin metal layer is typically used as the cathode (hole-collecting) contact in both substrate and superstrate chalcogenide thin film solar cells. Molybdenum prepared by magnetron sputtering in vacuum is preferred for high-efficiency CIGS solar cells because of its high electrical conductivity of $5 \times 10^{-6} \Omega \mathrm{cm}$, an acceptable corrosion resistance, and importantly, the ability to build a $\mathrm{MoSe}_{2}$ intermediate layer providing a quasi-ohmic contact at the CIGS/Mo interface. Since the Mo back contact is deposited on non-conductive substrates (glass or polymer) to enable the monolithical interconnection of individual cells, only electroless solution approaches may be considered as alternatives to sputtering. The electroless metal deposition consists of several electrochemical partial reactions, such as the cathodic deposition of the respective alloy components and the anodic oxidation of the reducing agent, typically phosphorous or boron-containing. ${ }^{[22]}$ The electroless deposition of pure Mo is challenging. ${ }^{[23]}$ There are a few reports of co-depositing nickel-molybdenum alloys with up to $17 \mathrm{at} \%$ Mo thanks to a better catalytic action of $\mathrm{Ni}$ ions, ${ }^{[24]}$ but the electrical 


\section{WILEY-VCH}

properties of such back contacts in CIS solar cells are inferior due to adhesion problems. ${ }^{[25]}$ Metal diffusion into the absorber layer, detrimental for solar cell performance, also has to be considered $^{[26]}$, and therefore, alternative options such as highly conductive $\mathrm{Ag}, \mathrm{Cu}, \mathrm{Al}$ and $\mathrm{Ni}$ metals or alloys printed from metal-containing inks ${ }^{[8]}$ are not useful. Solution-processed graphitic materials ${ }^{[27]}$ or conductive metal oxides could be promising, although their applicability to CIGS solar cells has still to be proven, and several associated challenges, such as the ability to provide an adequate Ohmic contact, sufficient corrosion and temperature stability, and tolerable diffusion of impurities into the absorber have to be resolved. Therefore, we consider the conventional molybdenum layer prepared with vacuum-based magnetron sputtering as currently the cheapest and the most appropriate back contact material onto which other functional layers can be deposited from solutions.

\subsection{Absorber layer}

\subsubsection{CIGS}

CIGS is a direct band gap material with an optical absorption coefficient of $3 \times 10^{4} \mathrm{~cm}^{-1}$ and the core light-absorbing functional layer of a CIGS solar cell. Polycrystalline CIGS absorber layers for cells with efficiencies $>20 \%$ are obtained by vacuum deposition methods such as co-evaporation ${ }^{[2,28,29]}$ or sputtering. ${ }^{[30]}$ Non-vacuum deposition methods have been intensively investigated as reflected in several reviews, ${ }^{[9,31-33]}$ and among them the most promising are two-step approaches where a precursor layer is coated from solutions, nanoparticle dispersions, or by ED followed by an annealing step under $\mathrm{S}, \mathrm{Se}$ and/or $\mathrm{H}_{2} \mathrm{Se}$ atmosphere. The nanoparticle route has achieved the highest efficiencies to date of up to $17.12 \%$ reported by company Nanosolar Inc. ${ }^{[34]}$ Other nanoparticle routes exhibit lower conversion efficiencies of devices ${ }^{[35-37]}$ and often employ $\mathrm{H}_{2}, \mathrm{H}_{2} \mathrm{Se}$, or $\mathrm{H}_{2} \mathrm{~S}$ gasses requiring special safety measures. ${ }^{[38]}$

True solution inks naturally overcome the need for particle pre-fabrication and stabilization, and thus present an up-scalable and less sophisticated option. Typically, 


\section{WILEY-VCH}

approaches thereby utilize a multistep process including the solution formulation, ink deposition by a coating technique, a drying step to remove the solvent residues and form a stable compound precursor, and a final conversion step at $400-600{ }^{\circ} \mathrm{C}$ under chalcogen atmosphere (Figure 2a).
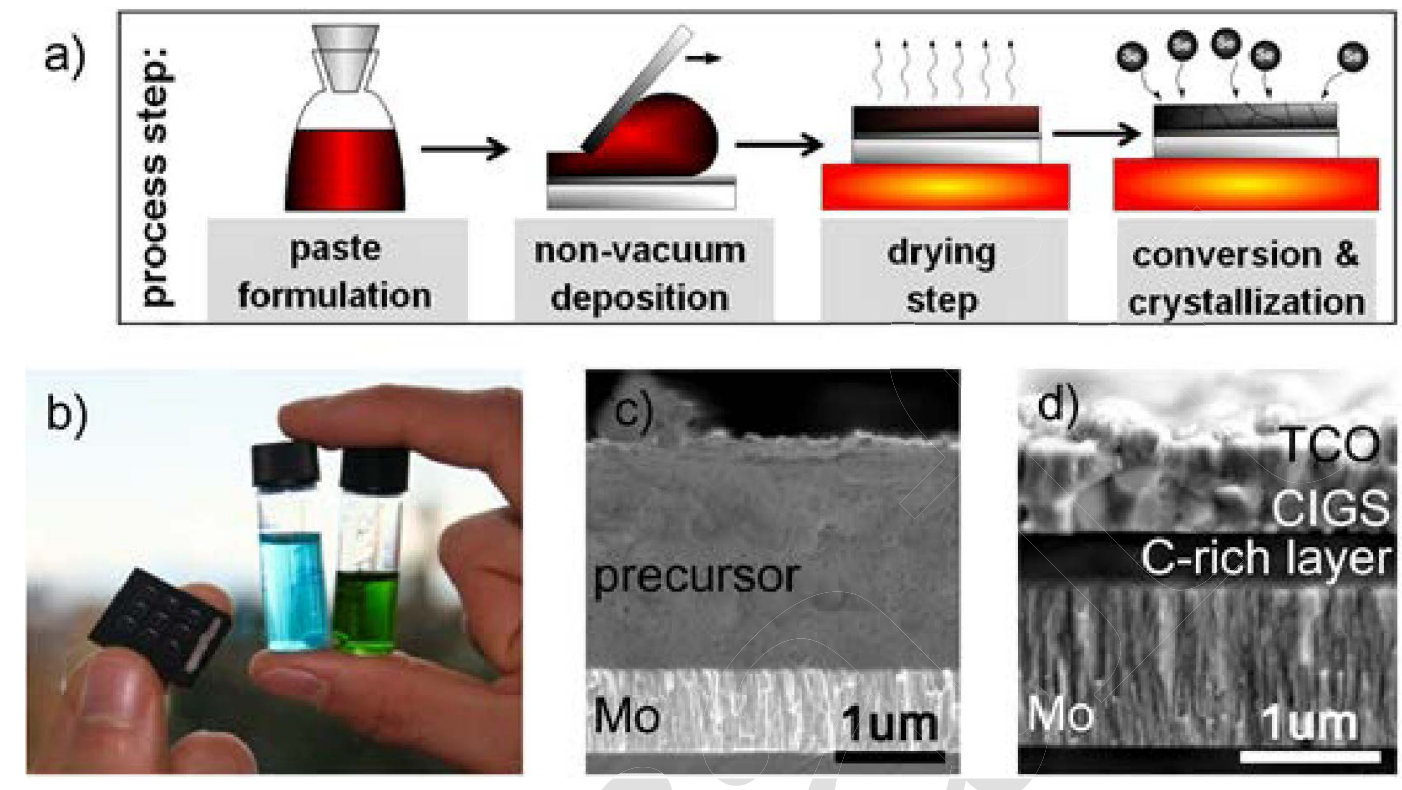

Figure 2. a) Processing sequence of solution-based deposition of CIGS layers on Mo-coated glass using knifecoating followed by drying and crystallization steps. b) True solutions of metal salts in 1,2-propane-diol solvent are employed. c) Dried precursor layer contains $\mathrm{Cu}$, In, Ga cations embedded into the organic matrix. d) Upon annealing in the selenium atmosphere the precursor is converted into a crystalline CIGS layer that is further covered with a CdS buffer, TCO layer, and Ni/Al grid to yield a CIGS solar cell with up to $7.7 \%$ efficiency. ${ }^{[43]}$ The carbon-rich layer formed at the Mo/CIGS interface as a result of the pyrolysis of the organic matrix is undesirable but still provides an adequate electrical contact. Part d) reproduced with permission. ${ }^{[43]}$ Copyright 2012, Wiley-VCH Verlag GmbH \& Co. KGaA.

High efficiency devices with solution deposited precursors have been obtained by the IBM group that published record efficiency values of up to $15.2 \%$ for $\mathrm{Cu}(\mathrm{In}, \mathrm{Ga})(\mathrm{Se}, \mathrm{S})_{2}$ devices from hydrazine-based inks. ${ }^{[39]}$ From a chemistry perspective, hydrazine can be considered an ideal solvent as it directly dissolves metal chalcogenides as well as chalcogen surplus, and can decompose cleanly without leaving any oxygen or carbon impurities. The major downside of hydrazine is its highly toxic and explosive nature, and this fact stimulates the research of safer non-hydrazine routes. Efficiencies up to $10.1 \%$ were obtained by Zhao et al. utilizing a 


\section{WILEY-VCH}

molecular precursor derived from butyldithiocarbamic acid. ${ }^{[40]}$ Other groups substituted toxic reagents with benign solvents or added binder materials to stabilize the metals but failed to improve device efficiencies. ${ }^{[41,42]}$ Uhl et al. have shown that even the omission of additional binder materials in the ink can still lead to residual carbon-rich layers between the absorber and back contact (Figure $2 \mathrm{c}$ and $2 \mathrm{~d}$ ). ${ }^{[43]}$ The in-situ formation of carboxylic acids from the redox reaction of nitrates with propanediol solvent leads to strong organic coordination of metal cations that prevents the loss of metals during heat treatments but results in the formation of a carbon-rich layer. Nevertheless, conversion efficiencies up to $7.73 \%$ were obtained with absorber thicknesses of only $500 \mathrm{~nm} \cdot{ }^{[43]}$ Wang et al. substituted nitrates with acetates and actylacetonates and employed a mixture of $\mathrm{H}_{2}$ and $\mathrm{N}_{2}$ gasses for the conversion to avoid the formation of the residual carbon and improve efficiencies to $8.01 \%{ }^{[44]}$ Low levels of residual carbon were also reported by Ahn et al. for a $7.72 \%$ efficient solar cell from ethanol solutions with monoethanolamine as coordinating ligand. ${ }^{[45]}$ Park et al. developed a precursor route that resulted in up to $8.28 \%$ efficient cells utilizing wide band gap CIGS absorber layers. ${ }^{[46]}$ The ink was based on methanol solutions of metal nitrates with polyvinyl acetate (PVA) binder material which was seen to decompose during the conversion with diluted $\mathrm{H}_{2} \mathrm{~S}$ vapors to leave a minimum of carbon residue and low degree of porosity.

The most established solution-based method for CIGS absorbers is electrodeposition (ED) which emerged in the early $80 \mathrm{~s}$ as a promising low-cost industrial alternative to PVD. ${ }^{[47,48]}$ ED can serve either to directly deposit the compound semiconductors $\mathrm{CuInSe}_{2}$ or $\mathrm{CuInS}_{2}{ }^{[49,50]}$ or to electroplate metallic $\mathrm{Cu}$-In or $\mathrm{Cu}-\mathrm{In}$-Ga precursors. ${ }^{[52-54]}$ In the case of metallic precursors, an annealing step at temperatures between 500 and $600{ }^{\circ} \mathrm{C}$ is used to react the precursor with chalcogens $(\mathrm{S}, \mathrm{Se})$ to form the semiconductor phase. In the case where all the precursor elements (Cu-In-Se-S) are already deposited by ED, the annealing is still mandatory to enable grain growth and improve layer crystallinity. An effective annealing is performed in closed reactors in order to maintain a high partial pressure of chalcogen which is 


\section{WILEY-VCH}

favourable for the $p$-type doping of CIGS. ${ }^{[55,56]}$. Research on ED-based processes and subsequent annealing led to efficiency improvements up to $11.3 \%$ in $2004 .^{[47]}$ In the $90 \mathrm{~s}$, NREL developed an alternative hybrid method to improve cell efficiencies further. It included an additional annealing step while co-evaporating $\mathrm{In}, \mathrm{Ga}$ and $\mathrm{Se}$ in order to tune the stoichiometry of the absorber resulting in efficiencies of up to $15.4 \%{ }^{[57]}$ That proved that high efficiency cells can be obtained from ED precursors even though the NREL process still involved a vacuum step. Another hybrid approach with one step electrodeposited $\mathrm{Cu}-\mathrm{In}-\mathrm{Ga}$ oxide precursor, which was reduced in hydrogen and then annealed in selenium, yielded an 12.4\% CIGS device. ${ }^{[58]}$ Persistent industrial research of electrodeposited $\mathrm{Cu} / \mathrm{In} / \mathrm{Ga}$ stacks enabled the fabrication of electrodeposition-based CIGS cells with efficiencies of $15.3 \%$ by company Solopower ${ }^{[59]}$ and $15.9 \%$ by company Nexcis. ${ }^{[60]}$ The Solopower ED process includes several steps where a $\mathrm{Cu}-\mathrm{In}$-Ga layer is electrodeposited first, followed by deposition of IIIA-VIA layers such as In-Se or Ga-Se. This stack is then subjected to rapid thermal annealing (RTA) to form the CIGS absorber. Nexcis uses a versatile process of the successive electrodeposition of $\mathrm{Cu}$, In and $\mathrm{Ga}$ elemental layers from water-based solutions (Figure 3a), which can be subsequently reacted either into $\mathrm{CuInS}_{2}{ }^{[61]} \mathrm{Cu}(\mathrm{In}, \mathrm{Ga}) \mathrm{Se}_{2}{ }^{[62]}$ or $\mathrm{Cu}(\mathrm{In}, \mathrm{Ga})(\mathrm{S}, \mathrm{Se})_{2}{ }^{[60]}$ during RTA between 500 and $600^{\circ} \mathrm{C}$ in a chalcogen-containing atmosphere under the atmospheric pressure and without the use of hazardous gases (e.g. $\mathrm{H}_{2} \mathrm{~S}$ and $\mathrm{H}_{2} \mathrm{Se}$ ). One of the strengths of this ED process is that the precursor can be easily engineered to deposit the $\mathrm{Cu}-\mathrm{In}-\mathrm{Ga}$ elemental layers with a tuneable compositional gradient across the absorber thickness. The annealing serves for grain growth and can also be used to reorganize elements in the absorber, which is particularly important for the two-step processes where Ga is known to segregate towards the back contact. The successive ED and chalcogenation of $\mathrm{Cu}-\mathrm{In}-\mathrm{Ga}$ layers yield absorbers with tightly stacked grains in the micrometer range (Figure 3b) similar to the morphology of PVD-grown material. 


\section{WILEY-VCH}

Table 1 presents a comparison of opto-electronic parameters for high-efficiency CIGS cells prepared by co-evaporation (the $20.4 \%$ solar cell from Empa on a flexible polymer foil $^{[29]}$ ) and ED. ${ }^{[60]}$ The main difference between co-evaporation and ED cells is in opencircuit voltage Voc and fill factor FF being lower for the ED cell. The difference in Voc is due to a lower content of gallium in the ED absorber, which results in a lower band gap of $1.01 \mathrm{eV}$ versus the band gap of $1.12 \mathrm{eV}$ for the evaporated absorber. Noteworthy, the difference between Eg/q and the Voc is $0.39 \mathrm{~V}$ for both the evaporated as well ED cells, indicating a comparable quality and number of voltage-limiting defects in both CIGS materials. To match the Voc of the co-evaporated cell the ED process must be tuned to produce an absorber with a higher gallium or sulfur content to reach a band gap close to 1.1-1.15 eV while keeping defects at the same low level. Further improvements of ED devices can be envisaged when applying the potassium-induced surface modification recently reported for evaporated absorbers. $^{[29]}$

a)

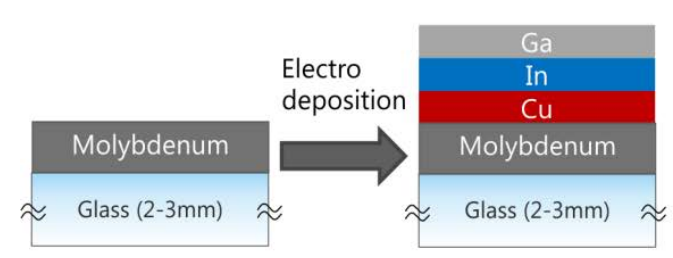

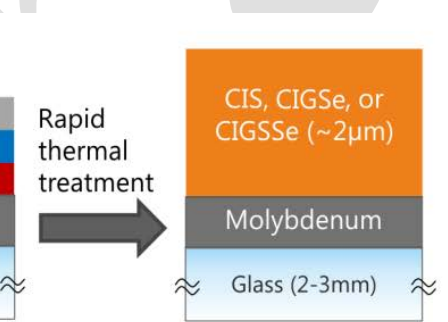

b)

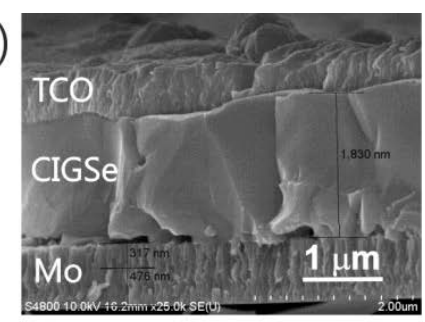

C)
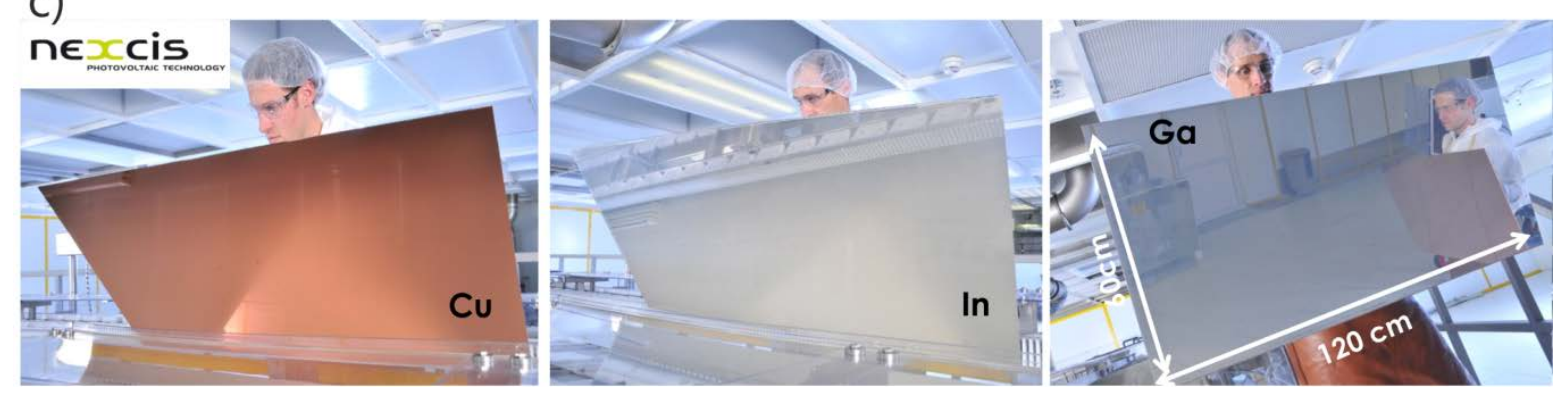

Figure 3. a) Sequential electrodeposition of $\mathrm{Cu}$, In, and $\mathrm{Ga}$ metal layers from aqueous solutions, followed by rapid thermal treatment in selenium-containing atmosphere to obtain the crystalline chalcogenide layer. b) SEM cross-section of the complete solar cell. c) Photographs of $\mathrm{Cu}$, In, and $\mathrm{Ga}$ electrodeposited metallic layers for $60 \times 120 \mathrm{~cm}^{2}$ commercial CIGS modules. 


\section{WILEY-VCH}

Table 1. Comparison of photovoltaic parameters of two high efficiency CIGS solar cells where the CIGS absorber is deposited by co-evaporation and electrodeposition. The electrodeposited cell has a lower band gap $E_{\mathrm{g}}$ due to a lower Ga content.

\begin{tabular}{ccccccc}
\hline Method & $\begin{array}{c}\text { Efficiency } \\
{[\%]}\end{array}$ & $\begin{array}{c}\text { Voc } \\
(\mathrm{mV})\end{array}$ & $\begin{array}{c}\text { Jsc } \\
\left(\mathrm{mA} / \mathrm{cm}^{2}\right)\end{array}$ & $\begin{array}{c}\mathrm{FF} \\
(\%)\end{array}$ & $\begin{array}{c}\mathrm{Eg} / \mathrm{q}- \\
\mathrm{Voc} \\
(\mathrm{mV})\end{array}$ & Ref. \\
\hline Co-evaporation & 20.4 & 736 & 35.1 & 78.9 & 384 & {$[29]$} \\
Electrodeposition & 15.8 & 619 & 34.6 & 73.8 & 390 & {$[60]$} \\
\hline
\end{tabular}

High deposition rate and high material utilization are two important advantages of ED as compared to other vacuum and non-vacuum techniques. The deposition of each of $\mathrm{Cu}$, In and Ga layers takes only a few tenth of seconds, and the material utilization of In and $\mathrm{Ga}$ species in the bath is expected to reach $95 \%$ in full production. One of the often encountered arguments against ED is that it is less homogeneous than PVD processes because the ED growth is strongly dependent on local substrate conductivity. The Mo coating on the substrate for ED must therefore be tuned and optimized to ensure a high, uniform lateral conductivity. Once these conditions are found, thickness deviations below 5\% and typically $3 \%$ are feasible for all metallic layers as calculated from over 200 points measured with X-ray fluorescence analysis on $60 \times 120 \mathrm{~cm}^{2}$ substrates. To compare, typical uniformities expected from coevaporation in-line system are in the $5 \%$ range $^{[63]}$ while the uniformity of the two-step sputtering processes have been reported in the range of $2 \% .{ }^{[64]}$ Taking into account the above arguments, the ED of individual metallic layers from water-based solutions with a subsequent annealing in a chalcogen atmosphere is suitable to obtain high-quality CIGS layers in an industrially scalable manner.

\subsubsection{CZTS}




\section{WILEY-VCH}

Kesterites, the compound chalcogenides comprising $\mathrm{Cu}_{2} \mathrm{ZnSnS}_{4}$ (CZTS), $\mathrm{Cu}_{2} \mathrm{ZnSnSe}_{4}$ (CZTSe) and mixed $\mathrm{Cu}_{2} \mathrm{ZnSn}(\mathrm{S}, \mathrm{Se})_{4}(\mathrm{CZTSSe})$, are often considered as possible alternatives to CIGS, where the costly In and Ga are replaced through cheaper and more abundant $\mathrm{Zn}$ and Sn. Kesterites are intrinsically $p$-type doped semiconductors with a high absorption coefficient $\alpha>10^{4} \mathrm{~cm}^{-1}$ and the direct band gap tunable in the range of $1.0-1.5 \mathrm{eV}$ by changing the $\mathrm{S} /(\mathrm{S}+\mathrm{Se})$ ratio. ${ }^{[10,65]}$ Since the device structure of kesterite solar cells is identical to that of CIGS, research and deposition strategies for kesterite absorbers are described hereafter.

Most research groups follow a two-step approach comprising a low temperature precursor deposition followed by a high temperature annealing in chalcogen-containing atmosphere, taking into account the thermal instability of the kesterite phase. ${ }^{[66,67]}$ The currently highest efficiency achieved from sputtered precursor stack followed by sulfurization is $10.8 \% .{ }^{[68]}$ The metal precursor can also be produced by the sequential electrodeposition of $\mathrm{Cu}, \mathrm{Zn}$, and $\mathrm{Sn}$ metals $^{[69]}$ or one-step ED of $\mathrm{Cu}-\mathrm{Sn}-\mathrm{Zn}$ layers ${ }^{[70]}$ to yield up to $7 \%$ and $5.8 \%$ devices, respectively. The most efficient kesterite solar cell to date with the conversion efficiency of $12.6 \%$ was fabricated by a solution approach in which $\mathrm{Cu}$ and $\mathrm{Sn}$ chalcogenides and a zinc salt were dissolved in hydrazine. ${ }^{[4]}$ Hydrazine is an ideal solvent with a strong reducing action and clean decomposition that yield high-quality CZTSSe absorbers but its use is restricted due to its toxicity and explosive nature. Another promising and less toxic route employs dimethyl sulfoxide (DMSO) as the solvent for metal salts and thiourea. ${ }^{[71]}$ The highest reported efficiency following the DMSO route is $>10.0 \% .{ }^{[72]}$ The precursor solution in DMSO is typically spin-coated in multiple cycles onto Mo-coated glass with an intermediate drying at $200-320{ }^{\circ} \mathrm{C}$ resulting in the fine-grained $\mathrm{Cu}-\mathrm{Zn}-\mathrm{Sn}-\mathrm{S}$ containing precursor (Figure 4a). The morphology of the final crystallized CZTS(Se) layer strongly depends on the annealing conditions as illustrated in Figure 4, where the precursor was annealed in a $\mathrm{N}_{2}$ or mixed $\mathrm{N}_{2}+\mathrm{Se}$ atmosphere in a tube flow furnace, or in closed systems 


\section{WILEY-VCH}

such as a graphite box or sealed quartz ampoules with Se pellets. ${ }^{[73]}$ Annealing in an inert atmosphere yields a large-grain CZTS material only if an excess of $\mathrm{Sn}$ is present in the precursor (Figure 4b), whereas the annealing in Se results in a smaller grain material and a significant loss of Sn (Figure 4c). ${ }^{[74]}$ The Sn loss can be partially reduced when sintering in closed systems providing a higher partial overpressure of chalcogen (Figure $4 \mathrm{~d}$ and $4 \mathrm{e}$ ), which yields the sintered top layer with large crystals. Despite the observed bi-layer morphology (Figure 4d) such an absorber can be processed into a solar cell with a conversion efficiency of $8.3 \%$, especially if $\mathrm{Na}$ dopant is present in the precursor solution. ${ }^{[75]}$
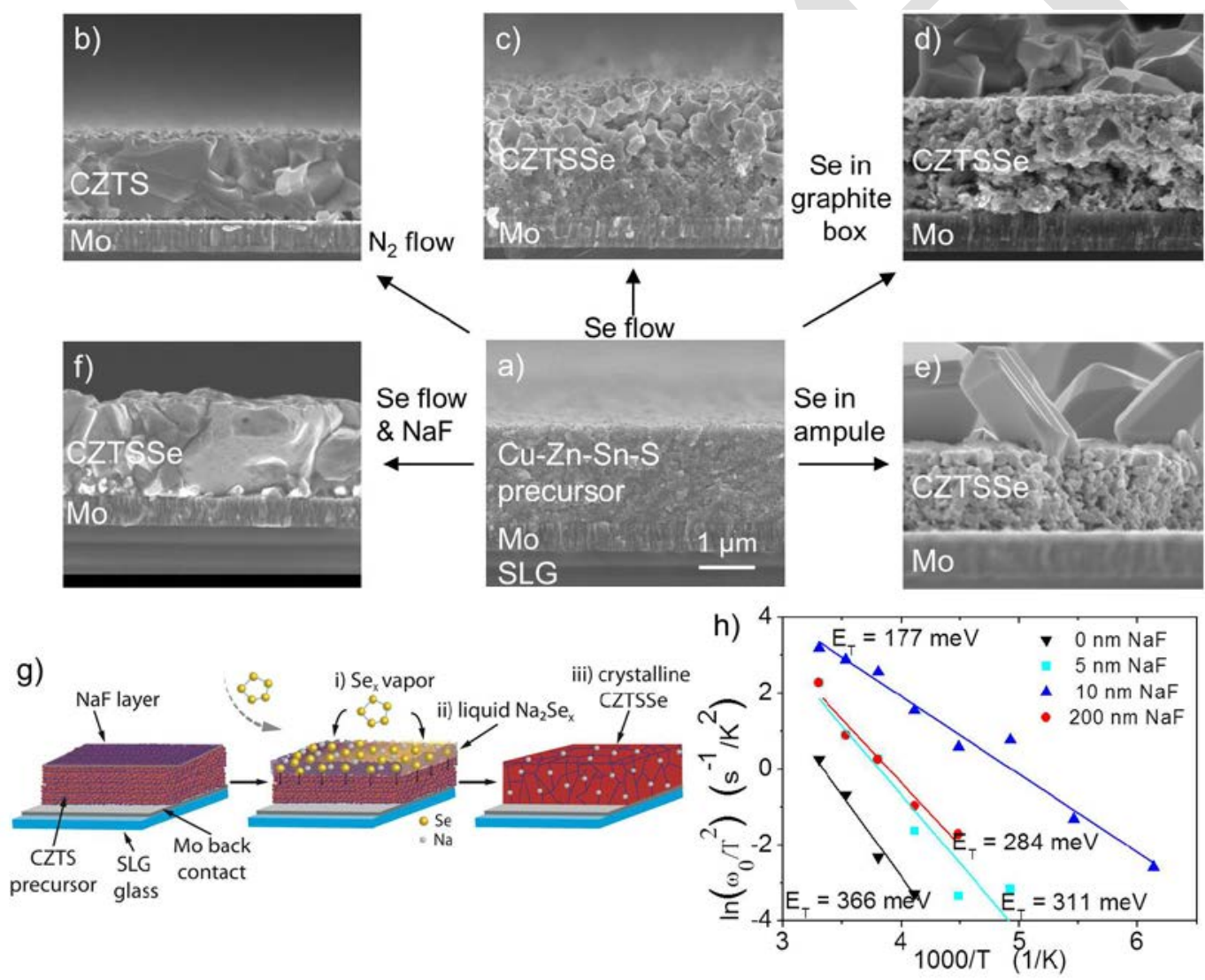

Figure 4. (a) SEM cross section images of the $\mathrm{Cu}-\mathrm{Zn}-\mathrm{Sn}-\mathrm{S}$ precursor that is converted into a crystallized layer upon annealing in $\mathrm{N}_{2}$ flow in a tube furnace (b), in selenium flow with $\mathrm{N}_{2}$ carrier gas in a tube furnace (c), in selenium atmosphere in a closed graphite box (d), with selenium overpressure in a sealed quartz ampule (e), and with additional $100 \mathrm{~nm} \mathrm{NaF}$ top layer during selenization in a tube furnace (f). The increased grain size in (f) as compared to (c) can be explained by the liquid $\mathrm{Na}_{2} \mathrm{Se}_{\mathrm{x}}$-assisted crystallization mechanism (g). The presence of the $\mathrm{NaF}$ top layer does not only influence the layer morphology but also changes electrical properties of the semiconductor layer, which can be seen from the variation of the defect activation energy derived from temperature-dependent capacitance-voltage measurements (h). Part (g) is reproduced with permission. ${ }^{[76]}$ Copyright 2014, American Chemical Society. 


\section{WILEY-VCH}

A promising approach to promote the grain growth in chalcogenide absorbers is to employ a pre-deposited $\mathrm{NaF}$ top layer which can lead to significantly improved layer morphology and grains extending over the whole layer thickness as seen in Figure $4 f^{[76]}$ The proposed recrystallization mechanism (Figure 4g) involves three steps: i) enhanced chemisorption of Se molecules due to the high affinity between $\mathrm{Na}$ and $\mathrm{Se},{ }^{[77]}$ ii) the formation of quasi-liquid $\mathrm{Na}_{2} \mathrm{Se}_{\mathrm{x}}$ phase at the surface, and iii) recrystallization of the CZTSSe solid by the reaction of the metal species with the reactive Se. An optimum amount of sodium not only improves the sintering but also enhances the solar cell performance. Temperaturedependent capacitance-frequency measurements ${ }^{[78]}$ performed in the $120-300 \mathrm{~K}$ range reveal that an optimum amount of $\mathrm{Na}$ (which corresponded to an equivalent $\mathrm{NaF}$ thickness of $10 \mathrm{~nm}$ in that particular case) results in the lowest activation energy of trap levels inside the CZTSSe absorber. $^{[73]}$

To conclude, the CZTSSe absorbers can be processed by solution routes but the material quality and the corresponding solar cell efficiencies are currently inferior to those for solution-processed CIGS absorbers.

\subsection{Buffer layer}

A thin layer of $n$-type semiconductor - the so called buffer layer - is used in high-efficiency chalcogenide solar cells in order to create a $p-n$ heterojunction for efficient charge separation. Apart from being an n-type semiconductor, the thin buffer layer should have a low absorption, a small lattice mismatch to the CIGS (CZTS) absorber, and importantly, to ensure a beneficial band alignment between the absorber and the front TCO contact. High efficiency CIGS devices typically employ an $n$-type $\mathrm{CdS}$ as the buffer whereas alternative $\mathrm{Cd}$-free materials such as $\mathrm{Zn}(\mathrm{S}, \mathrm{O}, \mathrm{OH}), \mathrm{ZnO},(\mathrm{Zn}, \mathrm{Mg}) \mathrm{O}, \mathrm{In}_{2} \mathrm{~S}_{3}$ are being actively investigated as well. ${ }^{[79]}$ Several 


\section{WILEY-VCH}

"buffer-free" concepts have also been reported but in each case a special treatment of the absorber surface was required or variations of $\mathrm{ZnO}$ were employed ${ }^{[80]}$ A number of review papers comprehensively describe the deposition of buffer layers by $\mathrm{CBD}$, atomic layer deposition (ALD), ion-layer gas reaction (ILGAR), ultrasonic spray pyrolysis (USP), metal organic chemical vapor deposition (MOCVD), ED, sputtering and evaporation (PVD) ${ }^{[79,81-84]}$ The "soft" non-vacuum methods prevail because they offer a conformal and uniform deposition of thin (30-100 nm) layers on the rough absorber surface without the concern of absorber damage as in the case of sputtering. In the following three sub-sections we will review three solution approaches proven to yield high-efficiency CIGS devices.

\subsubsection{Chemical bath deposition of $\mathrm{CdS}$ and $\mathrm{Zn}(\mathrm{S}, \mathrm{O}, \mathrm{OH})$}

$\mathrm{CBD}$ is the most common method for deposition of thin (tens of nanometers), conformal and pinhole-free CdS layers. Aqueous solutions of cadmium acetate or sulfate, thiourea as sulfur source and ammonia are mixed. The samples are then immersed into the stirred solution and left for 10-45 minutes during constant heating of the bath at $60-80{ }^{\circ} \mathrm{C}$. The basic ammonium solution ensures the coordination of $\mathrm{Cd}$ and the controlled chemical reaction to sulphide, although it is also thought to be crucial for the cleaning of absorber surface by removing oxides and other impurities. ${ }^{[79]}$ In addition, n-type doping of the CIGS region close to the surface by $\mathrm{Cd}$ or $\mathrm{Zn}$ cations from the $\mathrm{CBD}$ solution has been reported. ${ }^{[79,85]}$

ZnS-based alternative buffer layers by $\mathrm{CBD}$ are of particular interest as they can match the CdS buffered devices in performance with the highest efficiency of $20.9 \%$ announced by Solar Frontier. ${ }^{[30]} \mathrm{Zn}$-compound buffer layers exhibit wider band gaps and therefore less light absorption than CdS, which should lead to improved current densities of solar cells. Most $\mathrm{CBD}$ recipes for $\mathrm{Zn}$-compound buffers follow a deposition route very similar to $\mathrm{CdS}$ as seen in Figure 5. Aqueous solutions of zinc sulfate, thiourea as sulfur source and ammonia are mixed together, and the deposition temperature is typically $60-80{ }^{\circ} \mathrm{C} .{ }^{[80,86-88]}$ Other than 


\section{WILEY-VCH}

$\mathrm{ZnSO}_{4}$ and thiourea, zinc acetate and thioacetamide (TAA) can also be used as metal and chalcogen source, respectively. ${ }^{[89]}$ After the deposition, samples are immediately rinsed with an ammonia containing solution to avoid the precipitation of undesirable $\mathrm{Zn}(\mathrm{OH})_{2}{ }^{[87,90]}$ It has been confirmed that the mixing order is crucial to facilitate the complex formation of either $\mathrm{Zn}(\mathrm{TU})_{\mathrm{x}}{ }^{2+}$ or $\mathrm{Zn}\left(\mathrm{NH}_{3}\right)_{\mathrm{x}}{ }^{2+}$ complexes. ${ }^{[91]}$ While the molar concentrations of $\mathrm{Zn}$ and $\mathrm{TU}$ are seen to increase deposition speeds, increasing the $\mathrm{NH}_{4} \mathrm{OH}$ concentration decreases the reaction by promoting the intermediate complex formation. More detailed description of the reaction chemistry can be found in literature. ${ }^{[22,93]}$

One of the most apparent differences between $\mathrm{CdS}$ and $\mathrm{Zn}(\mathrm{S}, \mathrm{O}, \mathrm{OH})$ buffer layers is the compositional variety in the latter. This can be explained by looking at the solubility products between the respective hydroxides, oxides, and sulfides which are considerably closer for the zinc compounds than for cadmium. ${ }^{[15]}$ Therefore it is more difficult to control the $\mathrm{Zn}(\mathrm{S}, \mathrm{O}, \mathrm{OH})$ stoichiometry, since zinc hydroxides and oxides tend to co-precipitate at $\mathrm{pH}$ of 10-12 typically used for the growth of buffer layers. The compositional ratio between zinc hydroxides, oxides, and sulfides determines the band gap of the buffer layer as well as the band gap alignment between the window, buffer, and absorber layer. Chemical gradients from sulfur-poor to sulfur-rich ${ }^{[89,94]}$ and vice versa ${ }^{[87]}$ have been reported in these buffer layers. The performance of $\mathrm{Zn}(\mathrm{S}, \mathrm{O}, \mathrm{OH})$-containing devices can vary depending on the absorber surface state $^{[95]}$, whereas their electrical characteristics are often metastable due to the decomposition of residual hydroxides ${ }^{[96]}$ and the photo-doping of defects in the buffer layers ${ }^{[97]}$. Therefore, various post-deposition treatments, ${ }^{[98]}$ modifications in the absorber stoichiometry or i- $\mathrm{ZnO}$ thickness, ${ }^{[95]}$ and the substitution of $\mathrm{i}-\mathrm{ZnO}$ for more resistive $(\mathrm{Zn}, \mathrm{Mg}) \mathrm{O}^{[99]}$ are being intensively investigated in order to obtain stable devices at maximized efficiency. 


\section{WILEY-VCH}
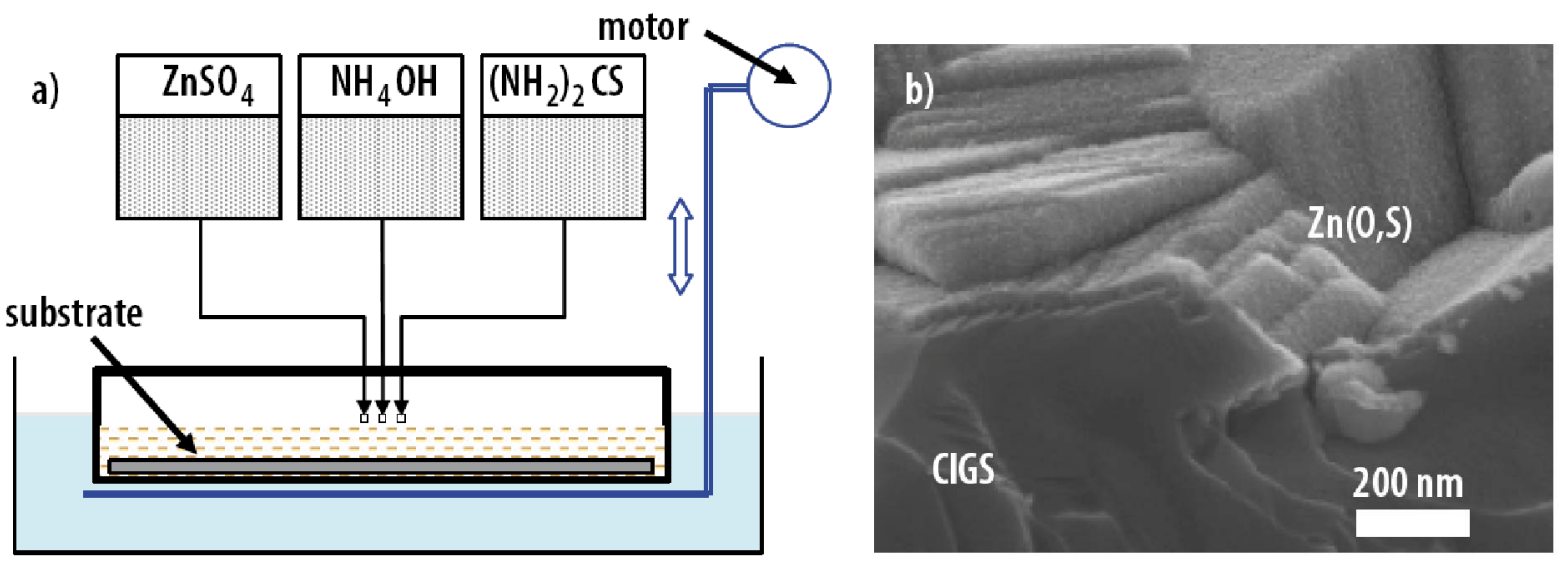

Figure 5. a) Scheme of $\mathrm{Zn}(\mathrm{S}, \mathrm{O}, \mathrm{OH})$ growth by $\mathrm{CBD}$ from the educts zinc sulfate, ammonium hydroxide, and thiourea, very similar to the growth of CdS by CBD. b) SEM image of an approximately $30 \mathrm{~nm}$ thick CBD $\mathrm{Zn}(\mathrm{S}, \mathrm{O}, \mathrm{OH})$ buffer layer on polycrystalline CIGS. Reproduced with permission. ${ }^{[81]}$ Copyright 2014 , Wiley-VCH Verlag GmbH \& Co. KGaA.

\subsubsection{ILGAR of $\operatorname{In}_{2} S_{3}$ and $\mathrm{ZnS}$}

Ion Layer Gas Reaction (ILGAR) is a sequential deposition method consisting of two steps: in the first step an intermediate precursor layer (ion layer) is deposited which is converted to the final thin film material employing a reactive gas such as $\mathrm{H}_{2} \mathrm{~S}$ (gas reaction). ${ }^{[100]}$ The cycle of precursor deposition and gas reaction can be repeated numerous times resulting in a uniform and high quality thin film layer with desired thickness. Originally ILGAR was carried out by dipping a substrate into a salt solution following a gas phase reaction. To overcome issues with low growth rates (1-2 $\mathrm{nm}$ per cycle) and to adapt the process for inline manufacturing, the process was extended to spray-ILGAR. ${ }^{[94]}$ With this procedure high quality buffer layers (mainly $\operatorname{In}_{2} \mathrm{~S}_{3}$ ) or window layers $(\mathrm{ZnO})$ can be deposited directly on the CIGS solar cell absorbers. By utilizing deposition temperatures below $200{ }^{\circ} \mathrm{C}$ for the $\operatorname{In}_{2} \mathrm{~S}_{3}$ buffer the highest efficiency of $16.8 \%$ was achieved. ${ }^{[98]}$ The deposition of $\mathrm{ZnS}$ by spray-ILGAR is also possible using zinc acetylacetonate precursor solution and $\mathrm{H}_{2} \mathrm{~S}$ as reactive gas, although no compact layer but a self-assembly of $\mathrm{ZnS}$ nanocrystals is obtained. ${ }^{[103]}$ This is attributed to a gas phase reaction and nucleation process with decomposition of the metal-organic precursor to $\mathrm{ZnO}$ and subsequent conversion to $\mathrm{ZnS}$ above reaction with $\mathrm{H}_{2} \mathrm{~S}$. The ILGAR-deposited $\mathrm{ZnS}$ 


\section{WILEY-VCH}

nanocrystals can act as a passivation layer on the CIGS surface, and in combination with an $\mathrm{In}_{2} \mathrm{~S}_{3}$ buffer the solar cell efficiency can be improved by about $1.5 \%$ absolutely as compared to a pure $\operatorname{In}_{2} \mathrm{~S}_{3}$ buffered cell. ${ }^{[104]}$ There are, however, numerous unresolved questions related to the influence of the ILGAR solution chemistry on surface defects depending on the $\mathrm{pH}$ value, ionic species, side reactions, etc. ${ }^{[105]}$

\subsubsection{Spray pyrolysis of $\operatorname{In}_{2} S_{3}$}

Spray pyrolysis (SP) is another coating method which can be integrated into a $\mathrm{R} 2 \mathrm{R}$ processing line for for large area deposition on glass or flexible foils. SP was first described in 1966 by Chamberlin and Skarman ${ }^{[106]}$ and has been used since then for various thin films. ${ }^{[107]}$ The substrate temperature determines the film morphology and crystallinity, and it is limited to about $250{ }^{\circ} \mathrm{C}$ in order to avoid the degradation of the CIGS/buffer interface and the oxidation of the absorber surface. Two buffer layers for CIGS solar cells, namely $\mathrm{CdS}^{[108]}$ and $\operatorname{In}_{2} \mathrm{~S}_{3}$, ${ }^{[109]}$ were deposited by SP. The precursor solution for the $\mathrm{In}_{2} \mathrm{~S}_{3}$ deposition consisted of $\mathrm{InCl}_{3}$ and thiourea dissolved in acetone and the substrate temperature was kept around $200{ }^{\circ} \mathrm{C}$ during spraying. The best efficiency achieved with that spray deposited $\operatorname{In}_{2} \mathrm{~S}_{3}$ buffer layer on a CIGS absorber was $13.1 \%{ }^{[109]}$

To sum up on available buffer approaches, the CBD of CdS from aqueous solutions remains a reliable and reproducible way of processing CIGS solar cells in the $18-20 \%$ range. The Cd-free $\mathrm{Zn}(\mathrm{OH}, \mathrm{O}, \mathrm{S})$ deposited by $\mathrm{CBD}$ or ILGAR have been proven to yield a comparable or even better performance but in that case a careful adjustment of the CIGS absorber and the TCO layer is required, and the device performance may be strongly affected by undesirable metastable effects. Solar cells with $\operatorname{In}_{2} \mathrm{~S}_{3}$ buffers currently exhibit inferior efficiencies.

\subsection{TCO front contact}




\section{WILEY-VCH}

An electrically conductive and transparent front contact is employed in chalcogenide solar cells to collect the photogenerated electrons while allowing the light to enter the solar cell absorber. ${ }^{[10]}$ Transparent conducting oxides (TCOs) are a unique class of materials that combine a high optical transparency $(>85 \%)$ with a low electrical resistivity $\left(\leq 10^{-3} \Omega \mathrm{cm}\right)$. Transparency in the visible range stems from the wide $(>3 \mathrm{eV})$ band-gap, whereas the low resistivity is a result of intrinsic and extrinsic doping of the oxide host resulting in a degenerate semiconductor with a high free electron concentration. Indium tin oxide $\left(\operatorname{In}_{2} \mathrm{O}_{3}: \mathrm{Sn}\right.$ or ITO) is often considered as a benchmark TCO that combines an extremely low resistivity of $<1 \times 10^{-4} \mathrm{Ohm} \mathrm{cm}$ and a high optical transmittance of $>90 \%$ together with a high corrosion stability. ${ }^{[111]}$ Because the high-quality ITO is typically sputtered at elevated temperature of 200-300 ${ }^{\circ} \mathrm{C}$ and the high market price of indium is dictated by its scarce availability, ${ }^{[112]}$ cheaper ZnO-based TCOs grown with low temperature PVD are currently preferred for chalcogenide solar cells. ${ }^{[110]}$ Intrinsic $\mathrm{ZnO}(\mathrm{i}-\mathrm{ZnO})$ is highly resistive because native point defects such as $\mathrm{Zn}$-on-O antisite $\left(\mathrm{Zn}_{O}\right)$, the $\mathrm{Zn}$ interstitial $\left(\mathrm{Zn}_{I}\right)$ and the $\mathrm{O}$ vacancy $\left(V_{\mathrm{O}}\right)$ cannot deliver sufficiently high donor concentrations. ${ }^{[13]}$ Substitutional doping with Al, In, Ga, B, Cl, or $\mathrm{F}$ does not only lead to high carrier concentrations of $10^{20}-10^{21} \mathrm{~cm}^{-3}$ but also improves the film corrosion resistance. ${ }^{[114]}$

High performance $\mathrm{ZnO}: \mathrm{Al}$ (AZO) films with resistivity as low as $1-2 \times 10^{-4} \Omega \mathrm{cm}$ are deposited on industrial scale by magnetron sputtering ${ }^{[15]}$ whereas $\mathrm{ZnO}$ : $\mathrm{B}(\mathrm{BZO})$ is grown by CVD. ${ }^{[16]}$ Non-vacuum approaches for preparing conductive ZnO-based layers include solgel, ${ }^{[117-119]}$ printing nanoparticle dispersions, ${ }^{[120,121]} \mathrm{ED}^{[122]} \mathrm{CBD},{ }^{[123-125]} \mathrm{SILAR}^{[126-128]}$ and $\mathrm{SP},{ }^{[129]}$ but a high deposition or post-annealing at temperatures of $300-600{ }^{\circ} \mathrm{C}$ is typically needed to achieve an adequate electrical resistivity in the range of low $10^{-3} \Omega \mathrm{cm}$. The solution growth of functional $\mathrm{ZnO}$ films and nanostructures is reviewed by Lincot $^{[130]}$, 


\section{WILEY-VCH}

whereas the recent comprehensive review by Pasquarelli et al. ${ }^{[131]}$ summarizes available solution approaches for TCOs and alternative transparent conductors.

The biggest challenge for preparing a highly conductive TCO contact is the limitation in maximum deposition/processing temperature because the CIGS/buffer p-n junction degrades irreversibly once heated above $250{ }^{\circ} \mathrm{C} .{ }^{[132]}$ While coating methods have failed to overcome this hurdle yet, solution growth methods such as $\mathrm{ED}^{[133]}$ and $\mathrm{CBD}^{[134]}$ were successful. In the case of ED, an aqueous solution of $\mathrm{Zn}$ salt with dissolved oxygen and/or nitrates as electrochemically active agents were used to grow highly conductive Cl-doped $\mathrm{ZnO}{ }^{[122,133]}$ Such $\mathrm{ZnO}: \mathrm{Cl}$ films exhibited remarkable optoelectronic properties with carrier density up to $10^{20} \mathrm{~cm}^{-3}$, the mobility of $20 \mathrm{~cm}^{2} \mathrm{~V}^{-1} \mathrm{~s}^{-1}$ and transmission in the visible range of $90 \%$ without exceeding a process temperature of $150{ }^{\circ} \mathrm{C}$. An evaporated CIGS solar cell with the $\mathrm{ED} \mathrm{ZnO}: \mathrm{Cl}$ window layer showed an efficiency of $15.8 \%$, - comparable to the reference cell with a sputtered AZO contact that gave $16.2 \%$. The ED approach is, however, applicable only on conductive substrates and may not always result in a homogeneous TCO layer because of local fluctuations in conductivity of the underlying glass/Mo/CIGS/CdS stack.

\subsubsection{Chemical bath deposition of AZO}

CBD offers the opportunity to use aqueous-, non-toxic solutions and low deposition temperatures $\left(<100{ }^{\circ} \mathrm{C}\right)$ coupled with fast growth rates and easy up-scaling. ${ }^{[135-137]}$ The CBD approach does not require a conducting substrate as in the case of electrodeposition, and is therefore more versatile for applications on insulating ceramic, glass and polymer substrates. This includes, for instance the electroless deposition of $\mathrm{ZnO}$ with a catalyst (e.g. dimethylaminoborane, DMAB $)^{[138]}$ or the deposition with a $\mathrm{Zn}$-ion chelating agent in alkaline solution. ${ }^{[124]}$ Recently our group developed a new route to deposit highly conductive $\left(\leq 5 \times 10^{-3}\right.$ Ohm $\mathrm{cm}$ ) and transparent ( $>90 \%$ in the visible range) AZO thin films using an aqueous CBD without exceeding $90{ }^{\circ} \mathrm{C}$ at any process step. ${ }^{[134]}$ The two main challenges to obtain 


\section{WILEY-VCH}

appropriate doping of the $\mathrm{ZnO}$ and omitting high temperature annealing have been overcome by using metallic aluminum as dopant combined with a post-deposition UV treatment. Due to corrosion of $\mathrm{Al}$ in basic aqueous solutions (Equation 1), a controlled and gradual release of $\mathrm{Al}$ ions to the CBD precursor solution is possible.

$$
\text { Eq.1 } \quad \mathrm{Al}^{0}+2 \mathrm{OH}^{-}+2 \mathrm{H}_{2} \mathrm{O} \rightarrow\left[\mathrm{Al}(\mathrm{OH})_{4}\right]^{-}+\mathrm{H}_{2} \uparrow
$$

This is of the utmost importance because $\mathrm{Al}$ ions (existent as $\left[\mathrm{Al}(\mathrm{OH})_{4}\right]^{-}$species in solution) suppress the $\mathrm{ZnO}$ growth at high $\mathrm{Al}$ concentrations. Using metallic $\mathrm{Al}$ as the dopant source ensures an auto-controlled release of the dopant species: low Al concentrations at the beginning of the deposition process for an undisturbed nucleation and initial growth and then gradually increasing $\mathrm{Al}$ concentrations for an efficient doping of $\mathrm{ZnO}{ }^{[134]}$

a

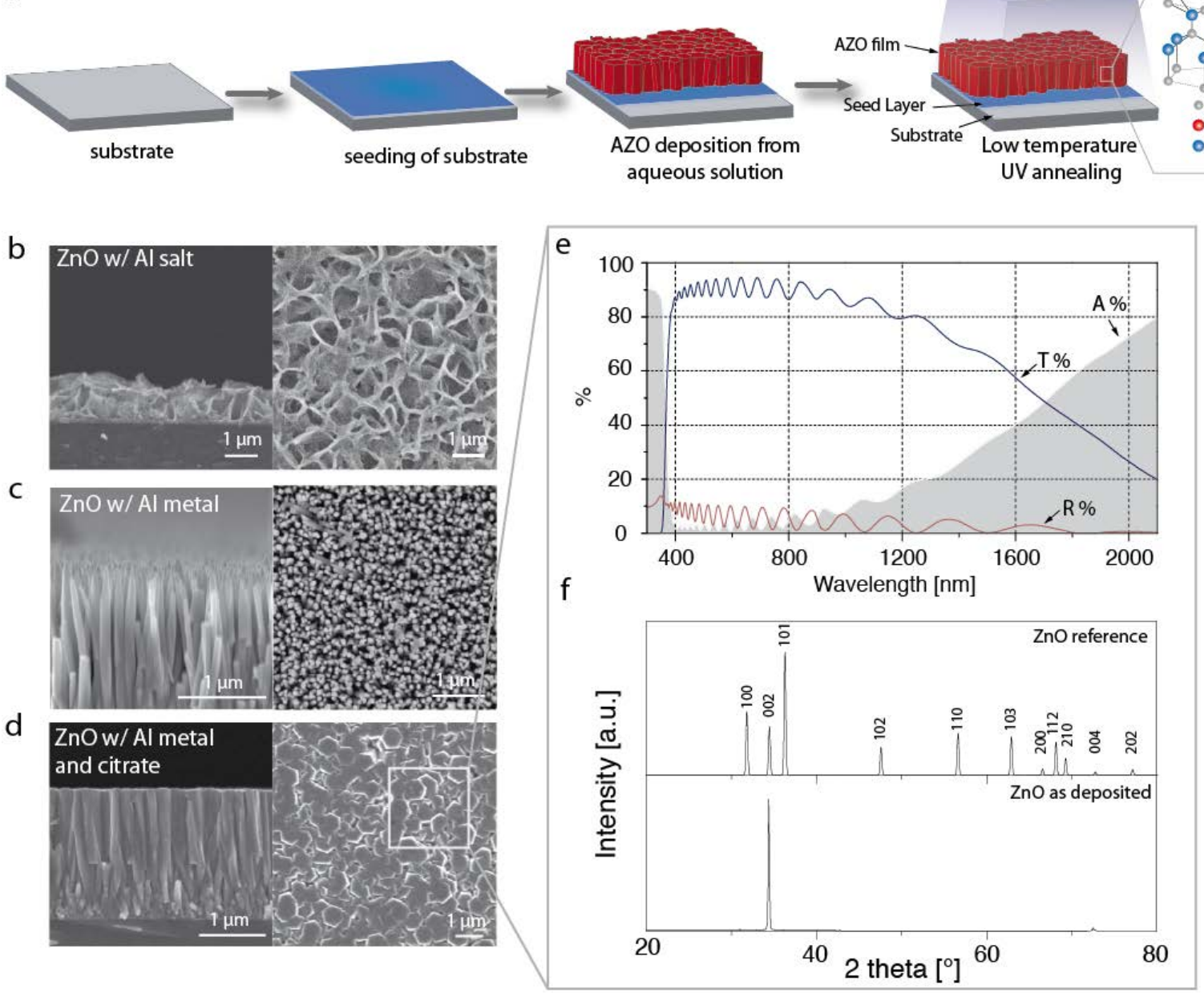

Figure 6. a) Schematic illustration of the aqueous CBD of conductive AZO layers. SEM top view and cross section images demonstrate the effect of the solution chemistry on the layer morphology: b) with $\mathrm{Al}$ salt as 


\section{WILEY-VCH}

dopant, c) with Al metal as dopant, and d) with Al metal as dopant and citrate as organic modifier. e) Transmittance, reflectance and absorptance of a $2 \mu \mathrm{m}$ thick AZO layer grown on a glass substrate. f) XRD pattern of as deposited AZO layer. Reproduced with permission. ${ }^{[134]}$ Copyright 2014, Wiley-VCH Verlag GmbH $\&$ Co. KGaA.

In Figure 6a the aqueous CBD approach is schematically illustrated. In the first step seeding of the substrate is performed to ensure the nucleation of a continuous film. Sol-gel processed $\mathrm{ZnO}{ }^{[139]}$ or solution precipitated $\mathrm{MnO}_{2}{ }^{[140]}$ can act as the seed. Very uniform AZO layers can be also grown on the $\mathrm{ZnO}$ seed layers which are obtained by spin-coating a saturated $\mathrm{ZnO}$ solution in $5 \mathrm{M} \mathrm{NH} \mathrm{NH}^{[141]}$ The growth of $\mathrm{AZO}$ takes place at from a supersaturated $\mathrm{ZnO}$ solution kept at $80-90{ }^{\circ} \mathrm{C}$ with ammonium citrate as organic modifier, and an ammonia/ammonia nitrate buffer to keep $\mathrm{pH}$ of $11-12 \cdot{ }^{[134]}$ For doping, an uncoated $\mathrm{Al}$ foil is immersed in the precursor solution right from the beginning of the deposition. After 60 minuntes of deposition, dense $2 \mu \mathrm{m}$ thick AZO films are obtained, which consist of $c$-axisoriented columns (Figure 6d) and exhibit a transmittance of $90 \%$ in the visible range (Figure 6f). To enhance electrical conductivity a low temperature UV treatment is performed. In the $\mathrm{UV} / \mathrm{Vis}$ spectra a distinct increase in the free carrier electron absorption is observed after the UV treatment (Figure 7a) going along with a decrease in sheet resistance by 4 orders of magnitude, - from about $200 \mathrm{k} \Omega$ sq to $20-50 \Omega$ sq. In XPS spectra the $\mathrm{O}_{1 \mathrm{~s}}$ signal is affected by the UV treatment (Figure 7b), where a shift from binding energies assigned to hydroxides to lower energies typical for metal oxides is observed. The aqueous solution process can be controlled in various ways as depicted in Figure 7c-f. By changing the immersed Al metal surface, the doping level can be tuned from 0.1 to 0.6 at $\%$. Deposition time from 15 to 120 minutes results in the film thickness from 0.8 to $3 \mu \mathrm{m}$. When the Al metal is immersed from the beginning a $\mathrm{Al}$ doping gradient is formed, whereas the removal of $\mathrm{Al}$ during deposition leads to an almost constant doping level in the film. This allows creating the doping profile similar to the $\mathrm{i}-\mathrm{ZnO} / \mathrm{AZO}$ stack in the same $\mathrm{CBD}$ run. 


\section{WILEY-VCH}

a

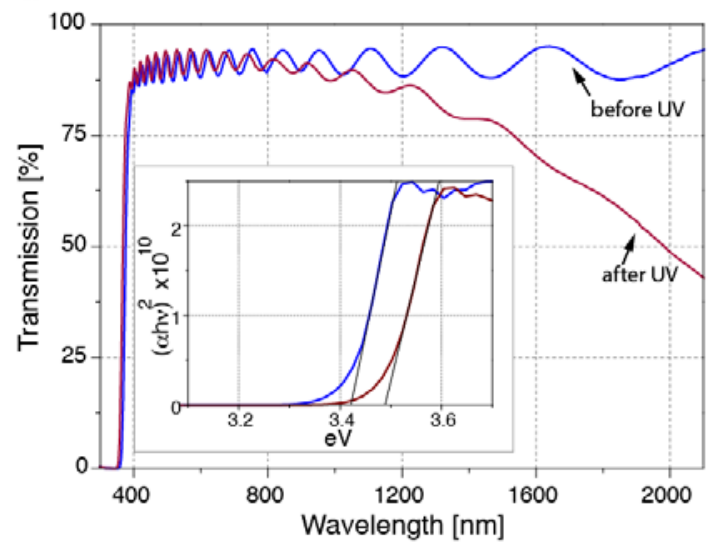

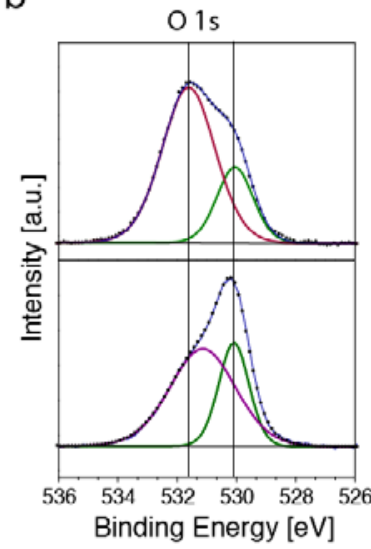

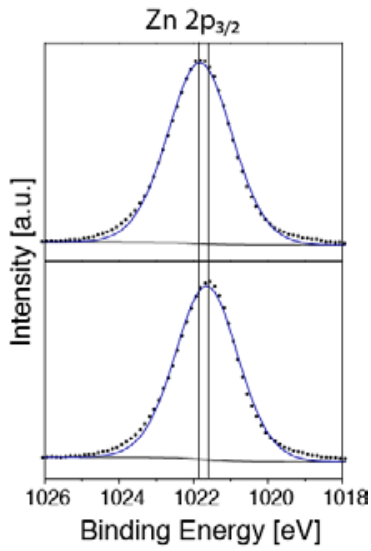

e

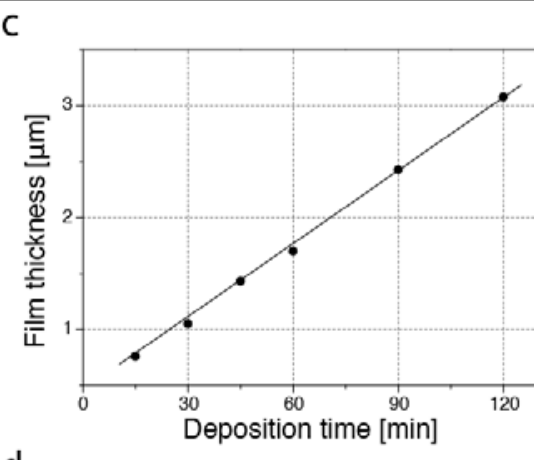

d

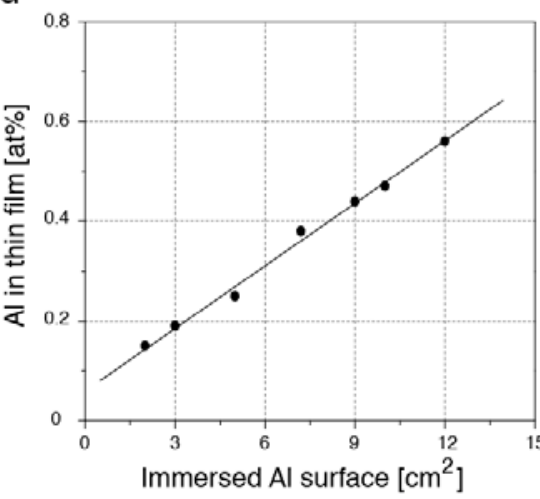

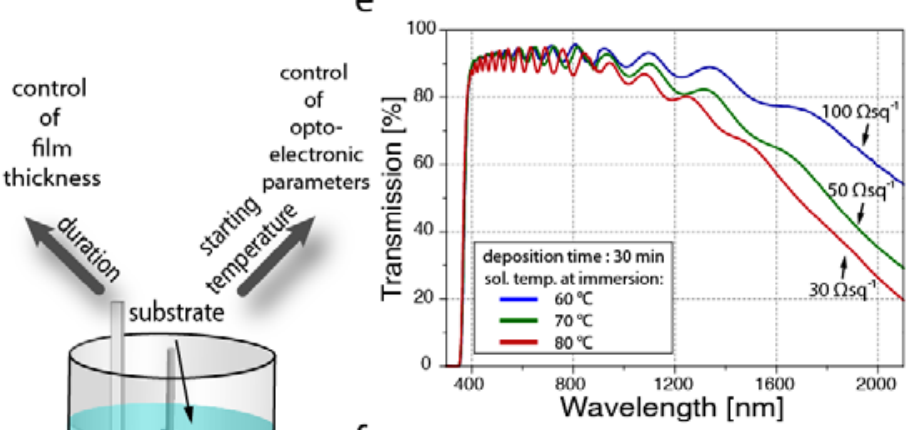

$f$

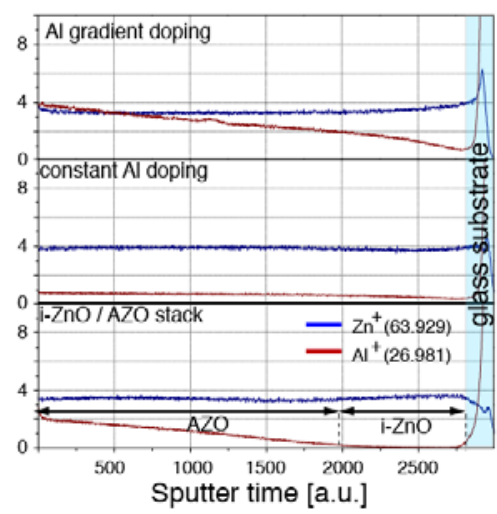

Figure 7. a) UV/VIS transmission spectra and b) XPS spectra $\left(\mathrm{O}_{1 \mathrm{~s}}\right.$ and $\left.\mathrm{Zn}_{2 \mathrm{p} 3 / 2}\right)$ of a CBD AZO layer before and after UV treatment. c-f) Doping level, film thickness, resistivity and doping gradient of CBD AZO layers can be tuned by controlling deposition time, dopant amount, deposition temperature, and the immersion point, respectively. Reproduced with permission. ${ }^{[134]}$ Copyright 2014, Wiley-VCH Verlag GmbH \& Co. KGaA.

To make the process independent from the $\mathrm{Al}$ corrosion kinetics, the constant increase of dopant concentration can be realized by the continuous addition of an Al-salt, thus mimicking the release of $\mathrm{Al}$ during metal corrosion. ${ }^{[141]}$ With this approach sheet resistance and optical performance are comparable to those with metallic $\mathrm{Al}$ as the doping source, ${ }^{[141]}$ 


\section{WILEY-VCH}

which paves the way for the incorporation of other dopant elements (e.g. halogens, B, Ga, or In).

\subsubsection{Spray pyrolysis of TCOs}

Spraying is another versatile method for depositing transparent and conductive TCO layers. It is a non-contact and large area deposition method that can be used as either liquid coating method or the direct growth method if the substrate temperature is high enough to induce the complete decomposition of the precursor solution. The latter variation is commonly referred to as spray pyrolysis (SP). Depending on how the solution mist is created, one distinguishes between pneumatic spray, ultrasonic spray, and electrostatic-assisted spraying. Effects of various spraying parameters on layer quality are discussed in reviews of Patil, ${ }^{[142]}$ and Perednis and Gauckler. ${ }^{[107]}$ Low viscosity $(<10 \mathrm{cP})$ solution are required for spraying and the droplet size is typically in the range of $5-50 \mu \mathrm{m}$ depending on the nozzle configuration and the drive frequency in case of ultrasonic spray. It is possible to spray more viscous solutions with aerosol jet, which allows a wider viscosity range of 1-2500 $\mathrm{cP}$ and can handle even particulate inks. ${ }^{[131]}$

Despite the versatility of SP, F-doped $\mathrm{SnO}_{2}$ (FTO) is the only commercial TCO for which this solution deposition is preferred. SP of solutions of tin chlorides in water or alcohols takes place at $350-550{ }^{\circ} \mathrm{C}$ directly on the hot surface of the floating soda-lime glass during its manufacturing. ${ }^{[143]}$ With this inexpensive approach not requiring an additional heating step, FTO hard coatings are deposited on million $\mathrm{m}^{2}$ scale primarily for fenestration and also as substrates for PV applications. Doped $\mathrm{In}_{2} \mathrm{O}_{3}{ }^{[144]}$ and $\mathrm{ZnO}^{[145]}$ were deposited first with SP, which later was fully replaced by PVD offering higher electrical conductivities even without the need to keep the glass above $500{ }^{\circ} \mathrm{C}$. There is a considerable amount of literature data on sprayed $\mathrm{ZnO}$ thin films over the last 40 years. ${ }^{[129,146-151]}$ In a typical deposition process, salts of zinc and appropriate dopant are dissolved in water or organic solvents such as 


\section{WILEY-VCH}

methanol, ethanol or isopropyl alcohol, and the solution is sprayed with an inert carrier gas onto a substrate heated to $300-600{ }^{\circ} \mathrm{C}$. The lowest resistivity was obtained for In-doped $\mathrm{ZnO}$ by Major et. al. in $1983,{ }^{[150]}$ when they reported the value of $(8-9) \times 10^{-4} \Omega \mathrm{cm}$ and an average visible transmittance of $85 \%$, the record that still stands today. The lowest resistivity value reported for AZO is around $3 \times 10^{-3} \Omega \mathrm{cm} .{ }^{[129,151]}$

Despite the numerous investigations of sprayed AZO films, only a few groups did actually implement them as front contacts in thin film solar cells. ${ }^{[151-154]}$ SP is attractive for depositing TCOs on thermally stable materials as glass, which can be used as a substrate for chalcogenide solar cells in the superstrate configuration, e.g. for CdTe solar cells. ${ }^{[151]}$ The need for high substrate temperature or post-annealing appears to be the main hurdle for using sprayed TCOs in CIGS solar cells. Some novel concepts, such as low-temperature $\mathrm{ZnO}$ precursors based on zinc ammine and hydroxyl nitrate compounds ${ }^{[155]}$ or combustion synthesis approaches to fabricate amorphous TCOs at temperatures as low as $200{ }^{\circ} \mathrm{C}^{[156]}$ should certainly be investigated to prove their potential for achieving conductive ( $<100 \Omega$ sq) and transparent $(>90 \%)$ contacts. While the electron mobility of solution-processed amorphous TCOs is already high enough for numerous demonstrations of thin film transistors $(\mathrm{TFT}),{ }^{[157]} \mathrm{PV}$ applications require a better in-plane carrier transport resulting in a low sheet resistance.

\subsection{ARC and metal grid}

Anti-reflection coating (ARC) is often employed in high-efficiency chalcogenide solar cells to decrease reflection losses of the front TCO contact, whereas metal grids are used to collect photogenerated electrons and transport them with low resistive losses. In "classical" CIGS solar cells a thin (ca. $100 \mathrm{~nm}$ ) $\mathrm{MgF}_{2}$ layer is used as ARC due to its low refractive index of 


\section{WILEY-VCH}

1.38 between that of air (1.0) and AZO (ca. 2.0). Bilayer of $\mathrm{Ni} / \mathrm{Al}$ and not $\mathrm{Ag}$ is often chosen for metal grids due to its good adhesion and high corrosion resistance. Both $\mathrm{MgF}_{2}$ and $\mathrm{Ni} / \mathrm{Al}$ are typically prepared by e-beam evaporation. Since no reports about solution-processed $\mathrm{MgF}_{2}$ or $\mathrm{Ni} / \mathrm{Al}$ could be found in literature, we will briefly review two alternative solutionprocessed materials, namely ZnO-based ARCs and Ag metal grids.

By depositing nanostructured $\mathrm{ZnO}$ on top of the $\mathrm{AZO}$ contact, or by structuring the AZO surface it is possible to decrease the effective refractive index of the surface for an antireflecting effect. Simultaneously, one increases scattering and enhances light trapping, which is important for very thin CIGS absorber layers suffering from insufficient light absorption. Such light management can be realized with $\mathrm{ZnO}$ nanoscale cones, needles, sheets, or nanorod arrays (NRAs) that display the so-called 'moth eye' effect for a reduced reflectance. $^{[158]}$ Methods of choice for the fabrication of ZnO-based ARCs are mainly $\mathrm{CBD},{ }^{[158]}$ hydrothermal growth, ${ }^{[159]}$ and $\mathrm{ED} .{ }^{[160,161]}$ Since the underlying AZO layer is conductive, ED can be applied and the morphology and optical performance of NRAs can be controlled by the cathodic potential and deposition time that determine $\mathrm{ZnO}$ nanorod density and length, respectively. ${ }^{[160,161]}$ Using hydrothermally grown ZnO NRAs on top of sputtered AZO contacts it was possible to reduce the reflection losses from $6.14 \%$ to $1.46 \%$ and thus to boost the cell efficiency from $10 \%$ to $11.5 \%$ (the efficiency rise, however, could not be attributed solely to the increased photocurrent due to reduced reflection). ${ }^{[162]}$ Beside $\mathrm{ZnO}$ derived $\mathrm{ARCs}, \mathrm{SiO}_{2}$ - and polymer-based coatings are worth mentioning since they can be prepared using sol-gel routes with post-curing at temperatures below $200{ }^{\circ} \mathrm{C} .^{[163]}$

Silver grids and contact lines are typically prepared from particle inks applied by screen-printing, but it is also possible to achieve highly conductive lines by ink-jetting true solutions. ${ }^{[8]}$ Thermally unstable $\mathrm{Ag}$ salts like silver nitrate, neodeconoate, and other carboxylates can be decomposed into metallic silver when processed at or above $150{ }^{\circ} \mathrm{C}$. Inkjet printed lines from such formulations achieve resistivity values of $2-3 \times 10^{-6} \Omega \mathrm{cm}$, which is 


\section{WILEY-VCH}

only slightly higher than the bulk $\operatorname{Ag}\left(1.6 \times 10^{-6} \Omega \mathrm{cm}\right) .{ }^{[8]}$ The thermal post-annealing can be eliminated if reducing agents such as alcohols and amines are added directly to the ink. For instance, Ag electrical contacts for CIGS cells were prepared by ink-jet printing a solution of Ag trifluoracetate in ethylene glycol onto a substrate preheated to $200{ }^{\circ} \mathrm{C}$. Even though a line resistivity of $2.06 \times 10^{-6} \Omega \mathrm{cm}$ was achieved, the prolonged exposure to the high temperature caused some degradation and limited the conversion efficiency to $11.4 \% .^{[8]}$

\section{All-solution processed CIGS thin film solar cell}

\subsection{Available literature data}

There is a vast amount of reports on CIGS (CZTS) solar cells where one or two functional layers were deposited with a solution approach. No examples of a solution processed metal back contact have been reported. The main focus has been on absorber layers, and the highest efficiencies of $15.2 \%$ and $15.9 \%$ have been achieved for CIGS absorbers prepared by hydrazine solution coating ${ }^{[39]}$ or $\mathrm{ED}^{[60]}$ respectively. All high efficiency CIGS cells do employ CBD grown $\mathrm{CdS}$ or $\mathrm{Zn}(\mathrm{O}, \mathrm{S})$ buffers. The solution processing of the front $\mathrm{TCO}$ contact, and specifically the $\mathrm{i}-\mathrm{ZnO} / \mathrm{AZO}$ bilayer, has been challenging due to the requirement of low $\left(<250{ }^{\circ} \mathrm{C}\right)$ processing temperature. Only recently conductive $\mathrm{ZnO}: \mathrm{Cl}$ and $\mathrm{AZO}$ layers could be grown by ED and $\mathrm{CBD}$ on top of sputtered i-ZnO/CdS/evaporated CIGS/Mo/glass structures to yield up to $15.8 \%{ }^{[133]}$ and $14.7 \%{ }^{[134]}$ efficient devices, respectively. All-solution processed solar cells are rare. There are reports on solution processed polymer bulk heterojunction, ${ }^{[164]}$ small organic molecule, ${ }^{[165]} \mathrm{CdSe}-\mathrm{CdTe}$ nanocrystal, ${ }^{[166]} \mathrm{Cu}_{2} \mathrm{O}-\mathrm{ZnO},{ }^{[167]}$ amorphous silicon, ${ }^{[168]}$ and finally, mixed halide perovskite solar cells, ${ }^{[169]}$ but in all those examples one electrode - typically the transparent conductive electrode - was deposited by sputtering. A noteworthy example is the CZTS solar cell with a CBD grown CdS buffer and a sol-gel processed i-ZnO/AZO bilayer, which exhibited an efficiency of $1.6 \%{ }^{[170]}$ 


\section{WILEY-VCH}

\subsection{Experimental results for all-solution processed solar cell (this work)}

Here we demonstrate an air-stable CIGS thin film solar cell in which all functional layers except metal back but including the conductive $\mathrm{i}-\mathrm{ZnO} / \mathrm{AZO}$ contact are deposited from true solutions of metal salts. Based on the argumentations from previous sections, we have chosen the following methods for maximizing the solar cell efficiency: magnetron sputtering for the Mo back contact, ED of metal precursors followed by reactive annealing in $\mathrm{Se}$ atmosphere for the CIGSSe absorber, CBD for the CdS buffer, spin-coating for the $\mathrm{i}-\mathrm{ZnO}$ interlayer, and finally, CBD for the AZO transparent conductive contact.

Molybdenum back contact was deposited by DC magnetron sputtering on soda-lime glass (SLG) substrates. The $\mathrm{Cu} / \mathrm{In} / \mathrm{Ga}$ multistack was electrodeposited from aqueous solutions with the technology of Nexcis company and converted into the CIGSSe absorber by RTA under Se atmosphere. The CIGSSe absorbers had a $\mathrm{Cu} /(\mathrm{In}+\mathrm{Ga})$ content of 0.9 and a low sulphur content resulting in a band gap of $1.01 \mathrm{eV}$. The CdS buffer layer was deposited from an aqueous solution bath with cadmium acetate, ammonium, and thiourea as the sulfur source. The resistive layer of $\mathrm{i}-\mathrm{ZnO}$ that later served as the seed layer for the AZO growth was deposited by spin-coating a saturated solution of $\mathrm{ZnO}$ in $5 \mathrm{M} \mathrm{NH}_{3}$. After drying at $100{ }^{\circ} \mathrm{C}$, a homogeneous i-ZnO layer with grains up to $50 \mathrm{~nm}$ was obtained. Finally, the growth of AZO took place in a basic aqueous solution saturated with $\mathrm{ZnO}$ at $80-90{ }^{\circ} \mathrm{C}$, with the addition of ammonium citrate $(1 \mathrm{mM})$ as organic modifier to ensure a dense crystal growth and an ammonia/ammonia nitrate $(1 \mathrm{M} / 0.05 \mathrm{M})$ buffer to adjust $\mathrm{pH}=11-12$. For doping an uncoated $\mathrm{Al}$ foil was immersed in the precursor solution right from the beginning of the deposition. To improve the electrical conductivity of the as-deposited AZO contacts, the UV treatment (70 $\mathrm{mW} / \mathrm{cm}^{2} \mathrm{UVA}$ ) was conducted for 10 min without intentional substrate heating, resulting in a sheet resistance of the AZO contact of about $20 \Omega$ sq. During the UV curing the substrate temperature did not exceed $140{ }^{\circ} \mathrm{C}$ at any point, as measured by a handheld thermocouple. Individual cells of $3 \times 3 \mathrm{~mm}^{2}$ were defined by mechanical scribing. No additional 


\section{WILEY-VCH}

antireflection coating or metal grid was applied. The cross-section of the cell is presented in

\section{Figure 8.}

a

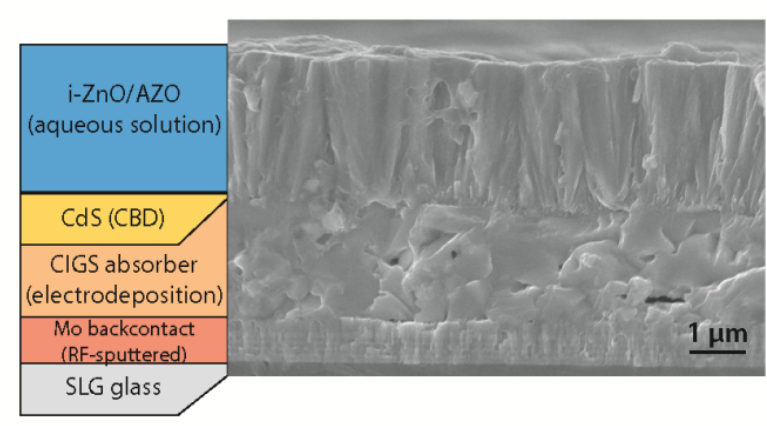

C

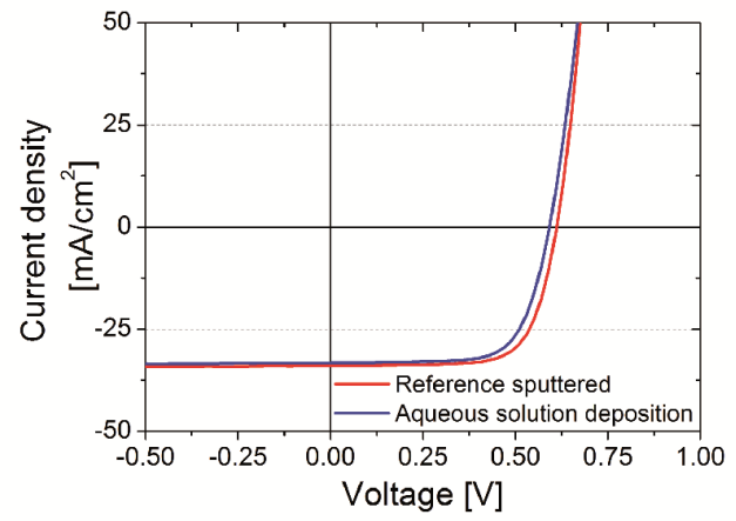

b

\begin{tabular}{c|c|c|c|c|} 
& Eff [\%] & Voc [mV] & Jsc $\left[\mathrm{mA} / \mathrm{cm}^{2}\right]$ & $\mathrm{FF}[\%]$ \\
\hline $\begin{array}{c}\text { Reference } \\
\text { sputtered }\end{array}$ & $14.9 \pm 0.3 \%$ & $613 \pm 2$ & $34.2 \pm 0.8$ & $71.2 \pm 0.4$ \\
$\begin{array}{c}\text { Aqu. sol. } \\
\text { deposition }\end{array}$ & $13.8 \pm 0.1 \%$ & $592 \pm 1$ & $33.4 \pm 0.2$ & $69.5 \pm 0.8$
\end{tabular}

d

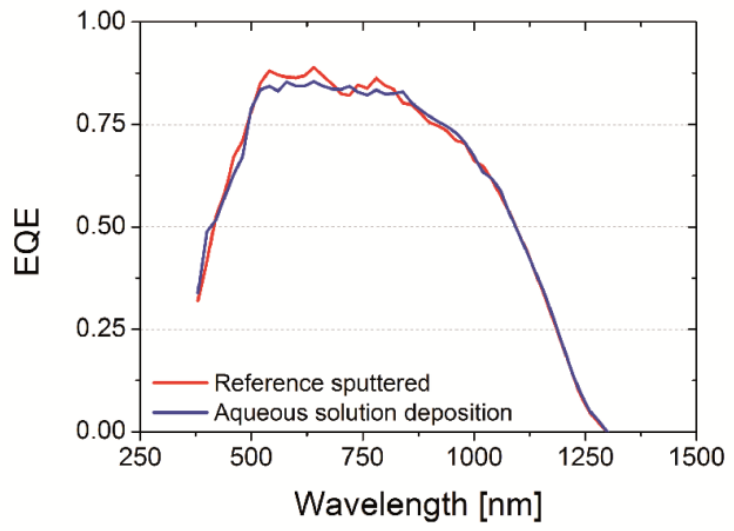

Figure 8. a) SEM cross section image of the solar cell with solution-deposited CIGS absorber, CdS buffer and i$\mathrm{ZnO} / \mathrm{AZO}$ front contact. b) Photovoltaic parameters of CIGS cells (average of three best cells) with sputtered and solution-grown i-ZnO/AZO on identical CIGS/CdS stacks. c) J-V and d) EQE curves of respective champion cells. Cell area was $0.09 \mathrm{~cm}^{2}$ and no antireflection coating or metal grid was applied.

Electrical characteristics of the three best cells are listed in Figure 8 highlighting the highest efficiency of $13.8 \pm 0.1 \%$ for the solution-processed CIGS solar cell. For comparison, the cells with a sputtered $\mathrm{i}-\mathrm{ZnO} / \mathrm{Al}: \mathrm{ZnO}$ bilayer on identical Mo/CIGS/CdS stack showed an efficiency of $14.9 \pm 0.3 \%$. The slightly lower short circuit current $J_{\text {sc }}$ can be attributed to the four times thicker CBD AZO layer as compared to sputtered AZO (2800 nm vs $700 \mathrm{~nm})$ to reach comparable sheet resistance. The lower open circuit voltage $V_{\mathrm{oc}}$ is probably related to the not-optimized $\mathrm{CdS} / \mathrm{i}-\mathrm{ZnO}$ interface, whereas the fill factor is similar for both cells. 


\section{WILEY-VCH}

\section{Conclusions}

By combining three solution approaches we have demonstrated the $13.8 \%$-efficient CIGS solar cell in which all functional layers (except the metal back contact) were processed from aqueous solutions. In particular, the CIGS absorber was obtained by ED with subsequent annealing in Se atmosphere, the CdS buffer and the AZO front contact were grown by CBD, whereas the intermediate $\mathrm{i}-\mathrm{ZnO}$ seed layer was prepared by spin-coating. The absolute device performance could certainly be improved by adding an antireflection coatings or metal grid on top. Another step for improvement is to replace the CdS buffer with a Cd-free $\mathrm{Zn}(\mathrm{O}, \mathrm{S})$ buffer that can also be grown with CBD.

The chosen solution approaches for CIGS, CdS, and AZO belong to the category of growth methods. This category seems to be more suitable to produce compact, uniform layers of polycrystalline semiconductors than the category of coating methods. The carrier transport in solution-processed covalent semiconductors is limited mostly by recombination at grain boundaries, voids, or impurities. In this respect, the growth methods such as ED or CBD, which inherently profit from the high mobility of ions in the liquid medium, can yield more compact layers with a lower content of solvent-induced impurities. The only drawback of the growth methods is that they can be performed mostly in batch-to-batch manner.

Even though solution based methods can be considered low-cost and easy up-scalable, deposition of a functional layer without loss in performance and deterioration of underlying layers is challenging. Therefore many industrial manufacturers still prefer vacuum deposition processes, simply due to superior performing devices justifying higher capital investment and running costs for sophisticated vacuum deposition tools. The quality and homogeneity of vacuum deposited layers in many cases is still better when compared to solution processing. Switching to solution technologies indeed makes sense only if comparable (or better) device performance is achieved, and (not or!) the cost of ownership can be reduced. In fact this is well demonstrated for the CdS or ZnS based buffer layer in chalcogenide thin film solar cells, 


\section{WILEY-VCH}

where the $\mathrm{CBD}$ approach is preferred over vacuum deposition due to better performance with lower cost of equipment. Another interesting approach as a possible alternative to vacuum deposition (although still in the stage of research) is the growth $\mathrm{f} \mathrm{Al}$ or Cl-doped $\mathrm{ZnO}$-based TCOs by ED or CBD. Further examples how solution processing can substitute vacuum deposition methods for chalcogenide based thin films solar cells are presented by companies like Nexcis or Solopower. Both are pursuing the electrodeposition of CIGS absorbers on large industrial scale. Their progress during the last years certainly gives a lot of confidence that solution processed solar cells have a great commercialization potential. In any case, the solution processing will certainly remain a very vibrant research field, where new lowtemperature approaches, novel materials and post-treatment concepts are waiting to be explored for applications not only in the field of photovoltaics.

\section{Acknowledgements}

Y. E. Romanyuk and H. Hagendorfer contributed equally to this work. The research leading to these results has received funding from the European Union's Seventh Framework Program FP7/2007-2013 under grant agreement n. 284486 (SCALENANO). A. R. Uhl acknowledges the financial support from the Swiss National Science Foundation (SNSF) under project number P2EZP2_152168.

\section{References}

Received: ((will be filled in by the editorial staff))

Revised: ((will be filled in by the editorial staff)) Published online: ((will be filled in by the editorial staff))

[1] M. A. Green, K. Emery, Y. Hishikawa, W. Warta, E. D. Dunlop, Prog. Photovolt: Res. Appl. 2014, 22, 701.

[2] Dirk Herrmann (Hanergy-Solibro), presented at 40th IEEE Photovoltaic Specialists Conference, Denver, CO, June 2014.

[3] First Solar, Media release from February 25, 2014, http://investor.firstsolar.com/releasedetail.cfm?ReleaseID=828273, accessed: August 2014 


\section{WILEY-VCH}

[4] W. Wang, M. T. Winkler, O. Gunawan, T. Gokmen, T. K. Todorov, Y. Zhu, D. B. Mitzi, Adv. Energy Mater. 2014, 4, 1301465.

[5] Best research-cell efficiencies, http://www.nrel.gov/ncpv/images/efficiency_chart.jpg, accessed: August 2014.

[6] Solexel, Media release from January 3, 2013, http://www.appliednanotech.net/news/130103_Solexel_Achievement.php, accessed: August 2014.

[7] D. B. Mitzi, Solution Processing of Inorganic Materials; John Wiley \& Sons, Hoboken, 2009.

[8] S. E. Habas, H. A. Platt, M. F. van Hest, D. S. Ginley, Chem. Rev. 2010, 110, 6571.

[9] T. Todorov, D. B. Mitzi, Eur. J. Inorg. Chem. 2010, 2010, 17.

[10] D. B. Mitzi, O. Gunawan, T. K. Todorov, K. Wang, S. Guha, Sol. Energy Mater Sol. Cells 2011, 95, 1421.

[11] Y. E. Romanyuk, C. M. Fella, A. R. Uhl, M. Werner, A. N. Tiwari, T. Schnabel, E. Ahlswede, Sol. Energy Mater. Sol. Cells 2013, 119, 181.

[12] S. Abermann, Sol. Energy 2013, 94, 37.

[13] M. Graetzel, R. A. J. Janssen, D. B. Mitzi, E. H. Sargent, Nature 2012, 488, 304.

[14] B. C. Bunker, P. C. Rieke, B. J. Tarasevich, A. A. Campbell, G. E. Fryxell, G. L. Graff, L. Song, J. Liu, J. W. Virden, G. L. McVay, Science 1994, 264, 48.

[15] G. Hodes, Chemical Solution Deposition of Semiconductor Films, Marcel Dekker, Inc., New York, USA, 2002.

[16] R. S. Mane, C. D. Lokhande, Mater. Chem. Phys. 2000, 65, 1.

[17] T. P. Niesen, M. R. de Guire, J. Electroceram. 2001, 6, 169.

[18] R.K. Pandey, S.N. Sahu, S. Chandra, Handbook of semiconductor electrodeposition, Marcel Dekker, New York, 1996.

[19] D. Lincot, Thin Solid Films 2005, 487, 40.

[20] A. A. Tracton, Coating Technology Handbook, Third Edition, CRC Press, Boca Raton, 2006.

[21] Part III, Deposition Techniques in Chemical Solution Deposition of Functional Oxide Thin Films, (Eds. T. Schneller, R. Waser, M. Kosec, D. Payne), Springer Verlag, Wien, 2013, Ch. 3. 


\section{WILEY-VCH}

[22] I. Ohno, in Modern Electroplating, (Eds: M. Schlesinger and M. Paunovic), John Wiley \& Sons, Inc., New York, 2010, Ch. 22.

[23] M. Ayoub, F. Dierre, R. L. Thompson, A. T. G. Pym, I. Radley, A. Basu, In 2009 IEEE Nuclear Science Symposium Conference Record (NSS/MIC); 2009; pp. 17971799.

[24] M. Schwartz, G. O. Mallory, J. Electrochem. Soc. 1976, 123, 606.

[25] B. Ghosh, D. P. Chakraborty, M. J. Carter, Semicond. Sci. Technol. 1996, 11, 1358.

[26] F. Pianezzi, S. Nishiwaki, L. Kranz, C. M. Sutter-Fella, P. Reinhard, B. Bissig, H. Hagendorfer, S. Buecheler, A. N. Tiwari, Prog. Photovolt: Res. Appl. 2014, DOI: 10.1002/pip.2503

[27] H. A. Becerril, J. Mao, Z. Liu, R. M. Stoltenberg, Z. Bao, Y. Chen, ACS Nano 2008, 2, 463.

[28] P. Jackson, D. Hariskos, R. Wuerz, W. Wischmann, M. Powalla, Phys. Status Solidi RRL 2014, 8, 219.

[29] A. Chirilă, P. Reinhard, F. Pianezzi, P. Bloesch, A. R. Uhl, C. Fella, L. Kranz, D. Keller, C. Gretener, H. Hagendorfer, D. Jaeger, R. Erni, S. Nishiwaki, S. Buecheler, A. N. Tiwari, Nat. Mater. 2013, 12, 1107.

[30] SolarFrontier, Media release from April 2nd 2014, http://www.solarfrontier.com/eng/news/2014/C031367.html, accessed: August 2014.

[31] M. Kemell, M. Ritala, M. Leskelä, Crit. Rev. Solid State Mater. Sci. 2005, 30. 1.

[32] C. J. Hibberd, E. Chassaing, W. Liu, D. B. Mitzi, D. Lincot, A. N. Tiwari, Prog. Photovolt: Res. Appl. 2010, 18, 434.

[33] D. Lee, K. Yong, Korean J. Chem. Eng. 2013, 30, 1347.

[34] G. Brown, P. Stone, J. Woodruff, B. Cardozo, D. Jackrel, In Proceedings of the 38th IEEE Photovoltaic Specialists Conference (PVSC); IEEE, 2012; pp. 003230-003233.

[35] C. Kind, C. Feldmann, A. Quintilla, E. Ahlswede, Chem. Mater. 2011, 23, 5269.

[36] Q. Guo, G. M. Ford, R. Agrawal, H. W. Hillhouse, Prog. Photovolt: Res. Appl. 2013, 21,64 .

[37] A. R. Uhl, P. Fuchs, A. Rieger, F. Pianezzi, C. M. Sutter-Fella, L. Kranz, D. Keller, H. Hagendorfer, Y. E. Romanyuk, F. LaMattina, S. Yoon, L. Karvonen, T. MagorianFriedlmeier, E. Ahlswede, D. VanGenechten, F. Stassin, A. N. Tiwari, Prog. Photovolt: Res. Appl., DOI: 10.1002/pip.2529.

[38] V. K. Kapur, A. Bansal, P. Le, O. I. Asensio, Thin Solid Films 2003, 431-432, 53. 


\section{WILEY-VCH}

[39] T. K. Todorov, O. Gunawan, T. Gokmen, D. B. Mitzi, Prog. Photovolt: Res. Appl. 2013, 21, 82 .

[40] W. Zhao, Y. Cui, D. Pan, Energy Technol. 2013, 1, 131.

[41] M. Kaelin, D. Rudmann, F. Kurdesau, H. Zogg, T. Meyer, A. N. Tiwari, Thin Solid Films 2005, 480-481, 486.

[42] A. R. Uhl, Y. E. Romanyuk, A. N. Tiwari, Thin Solid Films 2011, 519, 7259.

[43] A. R. Uhl, C. Fella, A. Chirilă, M. R. Kaelin, L. Karvonen, A. Weidenkaff, C. N. Borca, D. Grolimund, Y. E. Romanyuk, A. N. Tiwari, Prog. Photovolt: Res. Appl. 2012, 20, 526.

[44] W. Wang, S.-Y. Han, S.-J. Sung, D.-H. Kim, C.-H. Chang, Phys. Chem. Chem. Phys. 2012, 14, 11154.

[45] S. Ahn, T. H. Son, A. Cho, J. Gwak, J. H. Yun, K. Shin, S. K. Ahn, S. H. Park, K. Yoon, ChemSusChem 2012, 5, 1773.

[46] S. J. Park, J. W. Cho, J. K. Lee, K. Shin, J.-H. Kim, B. K. Min, Prog. Photovolt: Res. Appl. 2014, 22, 122.

[47] D. Lincot, J. F. Guillemoles, S. Taunier, D. Guimard, J. Sicx-Kurdi, A. Chaumont, O. Roussel, O. Ramdani, C. Hubert, J. P. Fauvarque, N. Bodereau, L. Parissi, P. Panheleux, P. Fanouillere, N. Naghavi, P. P. Grand, M. Benfarah, P. Mogensen, O. Kerrec, Sol. Energy 2004, 77, 725.

[48] V. S. Saji, I.H. Choi, C.W. Lee, Sol. Energy 2011, 85, 2666.

[49] R. N. Bhattacharya, J. Electrochem. Soc. 1983, 130, 2040.

[50] R. N. Bhattacharya, D. Cahen, G. Hodes, Sol. Energy Mater. 1984, 10, 41.

[51] R. N. Bhattacharya, K. Rajeshwar, Sol. Cells 1986, 16, 237.

[52] G. Hodes, T. Engelhard, C. R. Herrington, L. L. Kazmerski, D. Cahen, Prog. Cryst. Growth Charact. 1984, 10, 345.

[53] G. Hodes, T. Engelhard, D. Cahen, L. L. Kazmerski, C. R. Herrington, Thin Solid Films 1985, 128, 93.

[54] G. Hodes, D. Cahen, Sol. Cells 1986, 16, 245.

[55] J. F. Guillemoles, P. Cowache, S. Massaccesi, L. Thouin, S. Sanchez, D. Lincot, J. Vedel, Adv. Mater. 1994, 6, 379.

[56] C. Guillén, J. Herrero, J. Electrochem. Soc. 1996, 143, 493. 


\section{WILEY-VCH}

[57] R. N. Bhattacharya, W. Batchelor, J. F. Hiltner, J. R. Sites, Appl. Phys. Lett. 1999, 75, 1431.

[58] A. Duchatelet, T. Sidali, N. Loones, G. Savidand, E. Chassaing, D.Lincot, Sol. Energy Mater. Sol. Cells 2013, 119, 241.

[59] S. Aksu, S. Pethe, A. Kleiman-Shwarsctein, S. Kundu, M. Pinarbasi, in Proceedings of 38th IEEE Photovoltaic Specialists Conference (PVSC), IEEE, 2012, pp. 003092 003097.

[60] V. Bermudez (Nexcis), presented at 5th Photovoltaics Thin-Film Week, Berlin, April 2013.

[61] C. Broussillou, M. Andrieux, M. Herbst-Ghysel, M. Jeandin, J. S. Jaime-Ferrer, S. Bodnar, E. Morin, Sol. Energy Mater. Sol. Cells 2011, 95, Supplement 1, S13.

[62] F. Oliva, C. Broussillou, M. Annibaliano, N. Frederich, P. P. Grand, A. Roussy, P. Collot, S. Bodnar, Thin Solid Films 2013, 535, 127.

[63] K. Zhang, R. Faber, Large Linear Copper Thermal Evaporation Source for CIGS Solar Cell Applications, http://www.vptec.com/documents/VPTVaporSourceforCIGS_000.pdf, accessed: August 2014.

[64] J. Palm, V. Probst, A. Brummer, W. Stetter, R. Tölle, T. P. Niesen, S. Visbeck, O. Hernandez, M. Wendl, H. Vogt, H. Calwer, B. Freienstein, F. Karg, Thin Solid Films 2003, 431-432, 514.

[65] S. Chen, A. Walsh, J.-H. Yang, X. G. Gong, L. Sun, P.-X. Yang, J.-H. Chu, S.-H. Wei, Phys. Rev. B 2011, 83, 125201.

[66] A. Redinger, D. M. Berg, P. J. Dale, S. Siebentritt, J. Am. Chem. Soc. 2011, 133, 3320.

[67] J. J. Scragg, T. Ericson, T. Kubart, M. Edoff, C. Platzer-Björkman, Chem. Mater. 2011, 23, 4625 .

[68] H. Hiroi, N. Sakai, T. Kato, H. Sugimoto, in Proceedings of $39^{\text {th }}$ IEEE Photovoltaic Specialists Conference (PVSC), IEEE, 2013; pp. 0863-0866.

[69] L. Guo, Y. Zhu, O. Gunawan, T. Gokmen, V. R. Deline, S. Ahmed, L. T. Romankiw, H. Deligianni, Prog. Photovolt: Res. Appl. 2014; 22, 58.

[70] C. Gougaud, D. Rai, S. Delbos, E. Chassaing, D. Lincot, J. Electrochem. Soc. 2013, $160, \mathrm{D} 485$.

[71] W. Ki, H. W. Hillhouse, Adv. Energy Mater. 2011, 1, 732.

[72] T. Schnabel, T. Abzieher, E. Ahlswede, presented at 40th IEEE Photovoltaics Specialists Conference (PVSC 40), Denver, CO, USA, June 2014.

[73] C. Sutter-Fella, PhD Thesis Nr 21883, ETH Zürich, April, 2014. 


\section{WILEY-VCH}

[74] C. M. Sutter-Fella, A. R. Uhl, Y. E. Romanyuk, A. N. Tiwari, Phys. Status Solidi A, DOI $10.1002 /$ pssa.201431147.

[75] M. Werner, C. M. Fella, Y. E. Romanyuk, A. N. Tiwari, Thin Solid Films, submitted 2014.

[76] C. M. Sutter-Fella, J. A. Stückelberger, H. Hagendorfer, F. La Mattina, L. Kranz, S. Nishiwaki, A. R. Uhl, Y. E. Romanyuk, A. N. Tiwari, Chem. Mater. 2014, 26, 1420.

[77] D. Braunger, D. Hariskos, G. Bilger, U. Rau, H. W. Schock, Thin Solid Films 2000, $361-362,161$.

[78] J. Heath, P. Zabierowski, in Advanced Characterization Techniques for Thin Film Solar Cells (Eds. D. Abou-Ras, T. Kirchartz, U. Rau), Wiley-VCH Verlag GmbH \& Co. KGaA, 2011; pp. 81-105.

[79] N. Naghavi, D. Abou-Ras, N. Allsop, N. Barreau, S. Bücheler, A. Ennaoui, C.-H. Fischer, C. Guillen, D. Hariskos, J. Herrero, R. Klenk, K. Kushiya, D. Lincot, R. Menner, T. Nakada, C. Platzer-Björkman, S. Spiering, A. N. Tiwari, T. Törndahl, Prog. Photovolt: Res. Appl. 2010, 18, 411.

[80] M. Bär, H.-J. Muffler, C.-H. Fischer, S. Zweigart, F. Karg, M. C. Lux-Steiner, Prog. Photovolt: Res. Appl. 2002, 10, 173.

[81] W. Witte, S. Spiering, D. Hariskos, Vak. Forsch. Prax. 2014, 26, 23.

[82] S. Siebentritt, Sol. Energy 2004, 77, 767.

[83] D. Hariskos, S. Spiering, M. Powalla, Thin Solid Films 2005, 480-481, 99.

[84] N. Naghavi, C. Hubert, A. Etcheberry, V. Bermudez, D. Hariskos, M. Powalla, D. Lincot, Prog. Photovolt: Res. Appl. 2009, 17, 1.

[85] T. Nakada, A. Kunioka, Appl. Phys. Lett. 1999, 74, 2444.

[86] T. Nakada, M. Mizutani, Y. Hagiwara, A. Kunioka, Sol. Energy Mater. Sol. Cells 2001, 67, 255.

[87] A. Ennaoui, M. Bär, J. Klaer, T. Kropp, R. Sáez-Araoz, M. C. Lux-Steiner, Prog. Photovolt: Res. Appl. 2006, 14, 499.

[88] R. N. Bhattacharya, M. A. Contreras, G. Teeter, Jpn. J. Appl. Phys. 2004, 43, L1475.

[89] D. Hariskos, R. Menner, P. Jackson, S. Paetel, W. Witte, W. Wischmann, M. Powalla, L. Bürkert, T. Kolb, M. Oertel, B. Dimmler, B. Fuchs, Prog. Photovolt: Res. Appl. 2012, 20, 534.

[90] C. Hubert, N. Naghavi, O. Roussel, A. Etcheberry, D. Hariskos, R. Menner, M. Powalla, O. Kerrec, D. Lincot, Prog. Photovolt: Res. Appl. 2009, 17, 470. 


\section{WILEY-VCH}

[91] I. Lauermann, T. Kropp, D. Vottier, A. Ennaoui, W. Eberhardt, E. F. Aziz, ChemPhysChem 2009, 10, 532.

[92] C. Hubert, N. Naghavi, B. Canava, A. Etcheberry, D. Lincot, Thin Solid Films 2007, 515,6032 .

[93] C. Hubert, N. Naghavi, A. Etcheberry, O. Roussel, D. Hariskos, M. Powalla, O. Kerrec, D. Lincot, Phys. Status Solidi A 2008, 205, 2335.

[94] T. Nakada, M. Hongo, E. Hayashi, Thin Solid Films 2003, 431-432, 242.

[95] M. Buffière, N. Barreau, L. Arzel, P. Zabierowski, J. Kessler, Prog. Photovolt: Res. Appl., DOI: 10.1002/pip.2451.

[96] K. Kushiya, O. Yamase, Jpn. J. Appl. Phys. 2000, 39, 2577.

[97] A. O. Pudov, J. R. Sites, M. A. Contreras, T. Nakada, H.-W. Schock, Thin Solid Films, 2005, 480-481, 273.

[98] T. Nakada, T. Kobayashi, T. Kumazawa, H. Yamaguchi, IEEE J. Photovolt. 2013, 3, 461.

[99] D. Hariskos, B. Fuchs, R. Menner, N. Naghavi, C. Hubert, D. Lincot, M. Powalla, Prog. Photovolt: Res. Appl. 2009, 17, 479.

[100] J. Möller, C.-H. Fischer, H.-J. Muffler, R. Könenkamp, I. Kaiser, C. Kelch, M. C. Lux-Steiner, Thin Solid Films 2000, 361-362, 113.

[101] C.-H. Fischer, N. A. Allsop, S. E. Gledhill, T. Köhler, M. Krüger, R. Sáez-Araoz, Y. $\mathrm{Fu}$, R. Schwieger, J. Richter, P. Wohlfart, P. Bartsch, N. Lichtenberg, M. C. LuxSteiner, Sol. Energy Mater. Sol. Cells 2011, 95, 1518.

[102] R. Sáez-Araoz, J. Krammer, S. Harndt, T. Koehler, M. Krueger, P. Pistor, A. Jasenek, F. Hergert, M. C. Lux-Steiner, C.-H. Fischer, Prog. Photovolt: Res. Appl. 2012, 20 , 855.

[103] Y. Fu, N. A. Allsop, S. E. Gledhill, T. Köhler, M. Krüger, R. Sáez-Araoz, U. Blöck, M. C. Lux-Steiner, C.-H. Fischer, Adv. Energy Mater. 2011, 1, 561.

[104] Y. Fu, R. Sáez-Araoz, T. Köhler, M. Krüger, A. Steigert, I. Lauermann, M. C. LuxSteiner, C.-H. Fischer, Sol. Energy Mater. Sol. Cells 2013, 117, 293.

[105] Y. Fu, T. Rada, C.-H. Fischer, M. C. Lux-Steiner, T. Dittrich, Prog. Photovolt: Res. Appl. 2014, 22, 44.

[106] R. R. Chamberlin, J. S. Skarman, Solid-State Electron. 1966, 9, 819.

[107] D. Perednis, L. J. Gauckler, J. Electroceram. 2005, 14, 103.

[108] J. B. Mooney, S. B. Radding, Annu. Rev. Mater. Sci. 1982, 12, 81. 


\section{WILEY-VCH}

[109] S. Buecheler, F. Pianezzi, C. Fella, A. Chirila, K. Decock, M. Burgelman, A. N. Tiwari, Thin Solid Films 2011, 519, 7560.

[110] E. Fortunato, D. Ginley, H. Hosono, D. C. Paine, MRS Bull. 2007, 32, 242.

[111] R. G. Gordon, MRS Bull. 2000, 25, 52.

[112] A. Feltrin, A. Freundlich, Renewable Energy 2008, 33, 180.

[113] Ü. Özgür, Y. I. Alivov, C. Liu, A. Teke, M. A. Reshchikov, S. Doğan, V. Avrutin, S.J. Cho, H. Morkoç, J. Appl. Phys. 2005, 98, 041301.

[114] K. Ellmer, J. Phys. D: Appl. Phys. 2001, 34, 3097.

[115] T. Minami, H. Nanto, S. Takata, Jpn. J. Appl. Phys. 1984, 23, L280.

[116] J. Steinhauser, S. Faÿ, N. Oliveira, E. Vallat-Sauvain, C. Ballif, Appl. Phys. Lett. 2007, 90, 142107.

[117] K. Nishio, S. Miyake, T. Sei, Y. Watanabe, T. Tsuchiya, J. Mater. Sci. 1996, 31, 3651.

[118] J. Alam, D. C. Cameron, J. Vac. Sci. Technol., A 2001, 19, 1642.

[119] O. Tari, A. Aronne, M. L. Addonizio, S. Daliento, E. Fanelli, P. Pernice, Sol. Energy Mater. Sol. Cells 2012, 105, 179.

[120] K. Tarasov, O. Raccurt, J. Nanopart. Res. 2011, 13, 6717.

[121] L. Luo, M. D. Rossell, D. Xie, R. Erni, M. Niederberger, ACS Sustainable Chem. Eng. 2013, $1,152$.

[122] J. Rousset, E. Saucedo, D. Lincot, Chem. Mater. 2009, 21, 534.

[123] M. Izaki, Y. Saijo, J. Electrochem. Soc. 2003, 150, C73.

[124] M. Miyake, H. Fukui, T. Hirato, Phys. Status Solidi A 2012, 209, 945.

[125] M. Kevin, G. H. Lee, G. W. Ho, Energy Environ. Sci. 2012, 5, 7196.

[126] S. Mondal, K. P. Kanta, P. Mitra, J. Phys. Sci. 2008, 221.

[127] A. E. Rakhshani, Appl. Phys. A 2008, 92, 413.

[128] R. Chandramohan, T. A. Vijayan, S. Arumugam, H. B. Ramalingam, V. Dhanasekaran, K. Sundaram, T. Mahalingam, Mat. Sci. Eng. B 2011, 176, 152.

[129] M. de la L. Olvera, A. Maldonado, R. Asomoza, R. Castanedo-Perez, G. TorresDelgado, J. Canetas-Ortega, J. Mater. Sci.: Mater. Electron. 2000, 11, 383.

[130] D. Lincot, MRS Bull. 2010, 35, 778. 


\section{WILEY-VCH}

[131] R. M. Pasquarelli, D. S. Ginley, R. O’Hayre, Chem. Soc. Rev. 2011, 40, 5406.

[132] J.F. Guillemoles, L. Kronik, D. Chaen, U. Rau, A. Jasanek, H.W. Schock, J. Phys. Chem. B, 2000, 104, 4849.

[133] J. Rousset, E. Saucedo, K. Herz, D. Lincot, Prog. Photovolt: Res. Appl. 2011, 19, 537.

[134] H. Hagendorfer, K. Lienau, S. Nishiwaki, C. M. Fella, L. Kranz, A. R. Uhl, D. Jaeger, L. Luo, C. Gretener, S. Buecheler, Y. E. Romanyuk, A. N. Tiwari, Adv. Mater. 2014, 26,632 .

[135] J. J. Richardson, F. F. Lange, Cryst. Growth Des. 2009, 9, 2570; J. J. Richardson, F. F. Lange, Cryst. Growth Des. 2009, 9, 2576.

[136] W.-H. Luo, T.-K. Tsai, J.-C. Yang, W.-M. Hsieh, C.-H. Hsu, J.-S. Fang, J. Electron. Mater. 2009, 38, 2264.

[137] J. S. Fang, W. H. Luo, C. H. Hsu, J. C. Yang, T. K. Tsai, J. Electron. Mater. 2012, 41, 122.

[138] M. Izaki, T. Omi, J. Electrochem. Soc. 1997, 144, 1949.

[139] C.H. Hsu and D.H. Chen, Nanotechnology 2010, 21, 285603.

[140] M. Kokotov, G. Hodes, J. Mater. Chem. 2009, 19, 3847.

[141] P. Fuchs, H. Hagendorfer, Y. E. Romanyuk, and A. N. Tiwari, Phys. Status Solidi A, DOI 10.1002/pssa.201431145.

[142] S. Patil, Mater. Chem. Phys. 1999, 59, 185.

[143] E. Shanthi, V. Dutta, A. Banerjee, K. L. Chopra, J. Appl. Phys. 1980, 51, 6243.

[144] J. M. Mochel (Corning Glass Works), U.S. Pat., 2564 707, 1951.

[145] S. Major, A. Banerjee, K. L. Chopra, Thin Solid Films 1984, 122, 31.

[146] J. M. Nobbs, F. C. Gillespie, J. Phys. Chem. Solids 1970, 31, 2353.

[147] J. Aranovich, A. Ortiz, R. H. Bube, J. Vac. Sci. Technol. 1979, 16, 994.

[148] A. F. Aktaruzzaman, G. L. Sharma, L. K. Malhotra, Thin Solid Films 1991, 198, 67.

[149] M. Krunks, E. Mellikov, Thin Solid Films 1995, $270,33$.

[150] S. Major, A. Banerjee, K. L. Chopra, Thin Solid Films 1983, 108, 333.

[151] A. Crossay, S. Buecheler, L. Kranz, J. Perrenoud, C. M. Fella, Y. E. Romanyuk, A. N. Tiwari, Sol. Energy Mater. Sol. Cells 2012, 101, 283.

[152] M. S. Tomar, F. J. Garcia, Thin Solid Films 1982, 90, 419. 


\section{WILEY-VCH}

[153] J. Wienke, B. van der Zanden, M. Tijssen, M. Zeman, Sol. Energy Mater. Sol. Cells 2008, 92,884 .

[154] P. Prathap, A. Suryanarayana Reddy, G. Ramachandra Reddy, R. W. Miles, K. T. Ramakrishna Reddy, Sol. Energy Mater. Sol. Cells 2010, 94, 1434.

[155] T. Meyers, J. T. Anderson, C. M. Hung, J. Thompson, J. F. Wager, D. A. Keszler, J. Am. Chem. Soc. 2008, 130, 17603.

[156] M.-G. Kim, M. G. Kanatzidis, A. Facchetti, T. J. Marks, Nat. Mater. 2011, 10, 382.

[157] D.-H. Lee, Y.-J. Chang, G. S. Herman, C.-H. Chang, Adv. Mater. 2007, 19, 843.

[158] Y.-J. Lee, D. S. Ruby, D. W. Peters, B. B. McKenzie, J. W. P. Hsu, Nano Lett. 2008, 8,1501 .

[159] J. W. Lee, B. U. Ye, D. Kim, J. K. Kim, J. Heo, H. Y. Jeong, M. H. Kim, W. J. Choi, J. M. Baik, ACS Appl. Mater. Interfaces 2014, 6, 1375.

[160] W. Ludwig, W. Ohm, J.-M. Correa-Hoyos, Y. Zhao, M. C. Lux-Steiner, S. Gledhill, Phys. Status Solidi A 2013, 210, 1557.

[161] R. Tena-Zaera, J. Elias, C. Lévy-Clément, Appl. Phys. Lett. 2008, 93, 233119.

[162] B.-K. Shin, T.-I. Lee, J. Xiong, C. Hwang, G. Noh, J.-H. Cho, J.-M. Myoung, Sol. Energy Mater. Sol. Cells 2011, 95, 2650.

[163] D. Chen, Sol. Energy Mater. Sol. Cells 2001, 68, 313.

[164] G. Dennler, M. C. Scharber, C. J. Brabec, Adv. Mater. 2009, 21, 1323.

[165] Y. Sun, G. C. Welch, W. L. Leong, C. J. Takacs, G. C. Bazan, A. J. Heeger, Nat. Mater. 2012, 11, 44.

[166] I. Gur, N. A. Fromer, M. L. Geier, A. P. Alivisatos, Science 2005, 310, 462.

[167] T. S. Gershon, A. K. Sigdel, A. T. Marin, M. F. A. M. van Hest, D. S. Ginley, R. H. Friend, J. L. MacManus-Driscoll, J. J. Berry, Thin Solid Films 2013, 536, 280.

[168] T. Masuda, N. Sotani, H. Hamada, Y. Matsuki, T. Shimoda, Appl. Phys. Lett. 2012, $100,253908$.

[169] D. Liu, T. L. Kelly, Nat. Photonics 2014, 8, 133.

[170] N. Moritake, Y. Fukui, M. Oonuki, K. Tanaka, H. Uchiki, Phys. Status Solidi C 2009, 6,1233 . 


\section{WILEY-VCH}

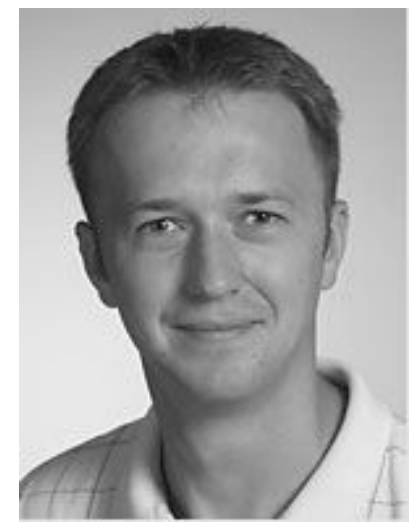

Yaroslav E. Romanyuk received his $\mathrm{PhD}$ from the Swiss Federal Institute of Technology, Lausanne in 2005. After his postdoctoral stay at the University of California, Berkeley, he joined Empa as a group leader in the Laboratory for Thin Films and Photovoltaics to research energy-related materials, TCOs and contact materials deposited by vacuum and low-cost, non-vacuum and solution techniques. He holds several patents and has co-authored more than 70 research articles.

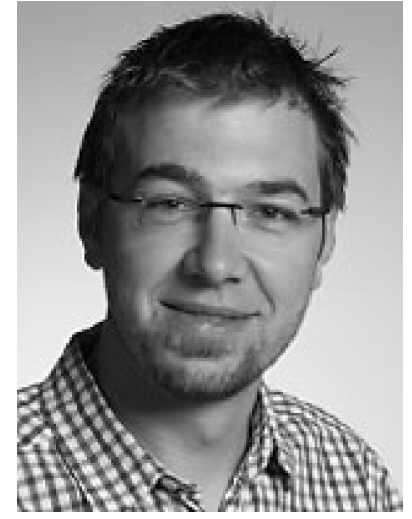

Harald Hagendorfer received his $\mathrm{PhD}$ from the Swiss Federal Institute of Technology, Lausanne in 2011. He joined the Laboratory of Thin Films and Photovoltaics as a PostDoc in 2012. His research interfaces environmental- and material science with an emphasis on inorganic chemistry. Currently he works on environmental friendly, sustainable, and low cost solution based methods for deposition of TCOs. He is co-author of more than 20 research publications in the field of analytical chemistry, environmental- and material science.

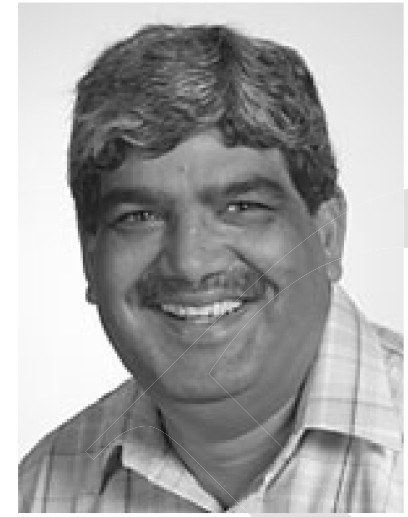

Ayodhya Nath Tiwari is the head of the Laboratory for Thin Films and Photovoltaics, Empa, Titular Professor at ETH Zürich, Switzerland and co-founder and chairman of company Flisom AG developing flexible CIGS solar modules. He has more than 30 years of R\&D experience in various photovoltaic technologies. He is a coauthor of more than 200 research publications and about 240 conference presentations including numerous invited papers and talks. Important contributions of Tiwari's group include the development of world record efficiency CIGS and CdTe solar cells on flexible substrates.

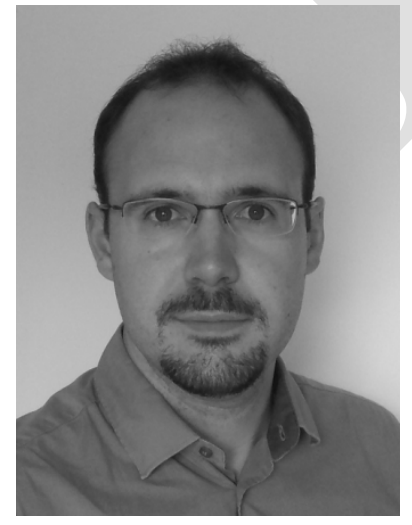

Cédric Broussillou received his M.Sc. from Ecole Polytechnique with a specialty in Materials for Energy in 2007 and obtained his $\mathrm{PhD}$ from Ecole des Mines de Paris in 2011. His PhD thesis dealt with the comprehension of the CIS absorber formation and was conducted partly at the Institute of Research \& Development on Photovoltaic Energy (IRDEP) in Paris and at the University of ParisSud. He is presently project manager for the company NEXCIS, working on efficiency improvements of CIGS modules. His research interests encompass photovoltaics, low-cost absorber processing, buffer and TCOs improvements, topics on which he has co-authored several articles and patents. 


\section{WILEY-VCH}

A $\mathrm{Cu}(\mathrm{In}, \mathrm{Ga}) \mathrm{Se}_{2}$ thin film solar cell with efficiency of $\mathbf{1 3 . 8 \%}$ is demonstrated where all constituent layers (except the metal back contact) are processed from aqueous solutions of metal salts using industrially-scalable processes.

Keywords: photovoltaic devices, semiconductors, solar cells, thin films, zinc oxide

Yaroslav E. Romanyuk*, Harald Hagendorfer, Patrick Stücheli, Peter Fuchs, Alexander R. Uhl, Carolin M. Sutter-Fella, Melanie Werner, Stefan Haass, Josua Stückelberger, Cédric Broussillou, Pierre-Philippe Grand, Veronica Bermudez, and Ayodhya N. Tiwari

All solution-processed chalcogenide solar cells - from single functional layers towards a $13.8 \%$ efficient CIGS device

ToC figure 